\title{
Soviet power plus electrification: What is the long-run legacy of communism?
}

\author{
Wendy Carlin ${ }^{\mathrm{a}, *}$, Mark Schaffer ${ }^{\mathrm{b}}$, Paul Seabright ${ }^{\mathrm{c}}$ \\ a University College London, Gower St, London, WC1E 6BT, UK and CEPR \\ ${ }^{\mathrm{b}}$ Heriot-Watt University, Edinburgh, EH14 4AS, UK, IZA and CEPR \\ c Toulouse School of Economics and Institute for Advanced Studies at the University of Toulouse, Manufacture des Tabacs, 21 allée de Brienne, \\ 31015 Toulouse Cedex 6, France and CEPR
}

\section{A R T I C L E I N F O}

\section{Article history:}

Received 29 May 2012

\section{JEL Classifications:}

043

P21

Keywords:

Infrastructure

Human capital

Institutions

Planned economy

Transition

Business environment

\begin{abstract}
A B S T R A C T
Two decades after the end of central planning, we investigate the extent to which the advantages bequeathed by planning in terms of high investment in physical infrastructure and human capital compensated for the costs in allocative inefficiency and weak incentives for innovation. We assemble and analyse three separate types of evidence. First, we find that countries that were initially relatively poor prior to planning benefited more, as measured by long-run GDP per capita levels, from infrastructure and human capital than they suffered from weak market incentives. For initially relatively rich countries the opposite is true. Second, using various measures of physical stocks of infrastructure and human capital we show that at the end of planning, formerly planned countries had substantially different endowments from their contemporaneous market economy counterparts. However, these differences were much more important for poor than for rich countries. Finally, we use firm-level data to measure the cost of a wide range of constraints on firm performance, and we show that after more than a decade of transition in 2002-05, poor ex-planned economies differ much more from their market counterparts, in respect to both good and bad aspects of the planning legacy, than do relatively rich ones. However, the persistent beneficial legacy effects disappeared under the pressure of strong growth in the formerly planned economies in the run-up to the global financial crisis.
\end{abstract}

(c) 2012 Elsevier Inc. All rights reserved.

\section{Introduction}

"Communism is government by the Soviets plus the electrification of the whole land.... Only when the economy has been electrified and modern heavy industry has become the technical basis of industry, agriculture and transportation, only then will we succeed at last."(V.I. Lenin, 1920)

This paper examines the effects of exposure to Soviet-style planning on long-r un economic development. We use two benchmarks to view the outcome of the large-scale planning experiment in the 20th century. In the first, we compare countries that were similar before planning was imposed. How did the countries exposed to planning fare in terms of long-run development as compared with countries that were at similar levels of development when planning began? In the second comparison, we take countries at similar levels of GDP per capita when planning ended and ask whether planning left countries different from their peers in ways that were

\footnotetext{
We have benefited from comments on related work in seminars and conferences at the EBRD, St Andrews, Oxford, UEA, the World Bank, UCL, Vienna and AISSEC in Macerata. We are grateful to Nick Crafts, Arturas Rozenas and to the Editor for comments on this paper. Some of the analysis in Section 4 of the paper builds on work in Carlin and Schaffer (2009), which was prepared as a background paper for Mitra et al. (2010). Wendy Carlin and Mark Schaffer have worked as consultants for the EBRD and the World Bank providing advice on the interpretation of the survey data used in this paper.

* Corresponding author.

E-mail addresses: w.carlin@ucl.ac.uk (W. Carlin), M.E.Schaffer@hw.ac.uk (M. Schaffer), paul.seabright@gmail.com (P. Seabright).
} 
likely to be important for their future development. The first perspective sheds light on the overall development trajectory due to planning and the second on particular qualitative features bequeathed to the countries that underwent the experience of planning.

Hypotheses about the impact of planning on development have a long history. Restricting attention to Soviet-style planning, they run from the lengthy debate in the 1930s on the merits of planning versus the market, through the evidence that accumulated in the sub-field of comparative economics in the post-war years to more recent evidence on the role of institutions such as competitive markets in fostering growth. We focus on two of the core ideas that emerge from these literatures. The first is that planning is detrimental to long-run economic growth, partly because of a wide range of static allocative inefficiencies, and partly because planning inhibits the adoption of higher productivity technologies and prevents the closure of low productivity enterprises and activities. Interference with the Schumpeterian processes of creative destruction weakens productivity growth by switching off both the incentive for enterprises to move a step ahead of the competition and the threat of bankruptcy. Market institutions external to firms, such as the rule of law, the control of corruption, a stable macroeconomic environment and the efficient administration of taxes, licenses and customs have also been identified as important in enabling the benefits of "the market" to be reaped.

The second thesis linking planning to development is that a symptom of the interference by planners in market processes was the priority given by them to investment in physical infrastructure and education. Adopting planning early in the process of industrialisation could generate rapid development and growth, and is the standard explanation for why the USSR grew rapidly in the 40 years after the adoption of the Stalinist planning system in 1928. Even in mature, industrialised economies, planning could be growth-promoting to the extent that market failures in capitalist market economies can prevent the adequate supply of public infrastructure and education. Since Soviet planning overrode some of the weaknesses of market systems as well as some of their strengths, an overall evaluation of the legacy of planning is likely to be complex, involving a trade-off between these two types of effect. The fact that the ideological fervour with which these questions were once debated has been diminishing as the Soviet Union recedes into history means that it is becoming easier than it used to be to approach the overall evaluation in a comparatively dispassionate frame of mind.

Recent historical research has already shed important light on the impact of planning on the growth of the countries that experienced it. Good and Ma (1999) construct a consistent series of per capita GDP from 1870 to 1989 for the present day states of Central and Eastern Europe. They use this to compare the performance of the countries in this region with those of the rest of Europe. Their overall conclusion is that there is "no systematic difference in growth rates between Central and Eastern Europe and the rest of Europe" (p. 114). One qualification is the period 1870-1910, prior to planning, "when growth tended to be about 0.2 percentage points faster in the region". A second is the period 1973-1989, "when growth was around 0.7 percentage points slower in the region". Overall, the implication is that planning did not make a clear difference to growth, at least until the period after 1973. What we do in the present paper is to show that this conclusion conceals an important difference between the countries concerned. Initially poor countries benefited from planning; initially more prosperous countries suffered from it. ${ }^{1}$

Crafts and Toniolo (2010), taking the analysis up until 2005, have a slightly more negative verdict on planning, noting that even if in the period from 1950-1973 "communism delivered growth rates only a little below those in Western Europe...this is not so impressive once the much greater scope for catch-up is taken into account"(p. 300). Chief among the reasons they cite for this discrepancy is that "the planning system rewarded managers who achieved production targets in the short term rather than those who found ways to reduce costs or improve the quality of output over the long term" (p. 315). More specifically, "the incentive structures used by the Soviet leadership to motivate managers and workers were a complex mixture of rewards, punishments and monitoring. Each of these became increasingly expensive over time, with the consequence that the viability of the system was threatened." (p. 323).

Broadberry and Klein (2011) use a detailed sectoral comparison of labour productivity between the UK and Czechoslovakia to cast light on why central planning was more successful at some tasks than at others. In particular they conclude that "central planning was able to achieve a satisfactory productivity performance during the era of mass production, but could not adapt to the requirements of flexible production technology during the 1980s" (p. 37). This suggests an important reason why the impact of planning should not be expected to be the same for countries at all levels of initial development. The results we show in this paper are entirely consistent with Broadberry and Klein's evidence about the source of planning's disadvantages; in addition we show that the source of planning's advantages lay principally in its emphasis on infrastructure and human capital.

Our analysis takes place in three steps. First, we use cross-country data on long-run performance to see whether the detrimental effects of the loss of market incentives when planning was imposed outweighed the potentially beneficial effects of interference in the market allocation through forced investments in physical infrastructure and education. Contrary to the view that planning was universally detrimental to development, we find that countries that were initially poor when they adopted planning did no worse and probably somewhat better by the end of the central planning era than their pre-planning peers. The countries that were relatively rich when planning was introduced, on the other hand, had levels of GDP per capita at the end of planning that were no better and probably somewhat worse compared to their pre-planning peers. In short, against the background of widely varying outcomes for market economies over this period, planning appears not to have worsened outcomes across the board. It may have improved them for the countries which industrialised under planning, but it made them worse for the countries which had already started or completed industrialising before planning began.

Whereas the first set of comparisons are made in terms of GDP per capita at the start and the end of planning, in the second step we compare aggregate measures of infrastructure and institutions in planned economies (PEs) with their contemporary GDP per capita market economy (ME) peers. Our 1988 snapshot tests the prediction that planning left these countries with higher levels of both physical infrastructure and education than was the case in countries at similar levels of GDP per capita. A follow-up

${ }^{1}$ Good and Ma do consider the relevance of initial levels of income, but the impact they examine is directly on the growth of GDP per capita. They do not consider the relevance of initial levels of income for the impact of planning on growth. See below. 
snapshot, in 2008, provides evidence on whether differences survived well into the period of transition following the abandonment of communism and planning in 1989-91, and also provides evidence on the institutional legacy of planning. The aggregate indicators show that the relative over-endowment of planned economies in education and physical infrastructure still persists 20 years after planning ended, particularly for the poorer countries. We also find some evidence that the legacy of weak market economy institutions persists.

Although the aggregate indicators of infrastructure and institutions provide useful information about the legacy of planning, they suffer from serious problems. First, they do not provide an accurate measure of the flow of services from the external environment to firms. Indicators of institutional quality are particularly noisy in this regard. Second, even if we can reliably distinguish the quality of such institutions as the rule of law in one country from that in another, this does not say anything about whether problems with the rule of law are more or less pressing for firms than are problems with, say, electricity. To understand whether the constraints on development left by planning were more or less important than the constraints faced by other countries, we need a different methodology.

This takes us to the third part of our analysis, where we show how firm-level survey data can be used to assess the impact of infrastructure, education and market institutions on firm growth. We apply the methods developed in Carlin et al. (2006, 2010) to the comparison between formerly planned and capitalist economies. We show how firm-level data can provide evidence on the comparative seriousness of inadequacies in a wide range of elements of the firm's physical and institutional environment. With these methods it is possible to go beyond quantitative differences in the indicators of infrastructure and institutions that are viewed as important for productivity growth. The question is not just whether there is more or less electricity or corruption in formerly planned versus market economies at similar levels of development, but how large is the impact of these elements of the external environment on firm growth. We compare the impact of both physical infrastructure and education - capturing the "forced development hypothesis" - and of market institutions across a large sample of transition and non-transition economies. The survey data allow us to evaluate the persistence of legacy effects in the second decade of transition and again after the phase of rapid growth prior to the global financial crisis.

\section{Planning versus the market: what do the long-run data show?}

A longstanding theme in the analysis of centrally planned economies is that of "static efficiency" versus "dynamic efficiency". The latter term, in this context, refers to growth and the rate of technological change. The Soviet Union, in this perspective, suffered from large static inefficiencies deriving from the many allocative failures of central planning, but nevertheless could and initially did - grow quickly because central planning was an effective mechanism for achieving high rates of capital accumulation and the absorption of new technologies.

A more modern version of this theme is to place the long-run growth of centrally planned economies in the context of technological catching-up. A poor country that adopted central planning could initially grow rapidly because of rapid industrialisation and high rates of investment in human and physical capital and infrastructure. Eventually, however, growth slows down because of catching-up and because capital stops growing faster than output. At this point, the static inefficiencies inherent in central planning dominate, and the country reaches an equilibrium productivity gap vis-à-vis the developed market economies (Gomulka 1986, 1988).

An interesting light is cast on the process by which central planning might lead to initially rapid growth in poor countries by the recent work of Allen (2012). He argues that the "great divergence" in national economic growth in the last nearly two centuries has been characterised by an almost complete lack of technical progress in the poorest countries: "It is remarkable that countries in 1990 with low capital labor ratios achieved an output per worker that was no higher than countries with the same capital labor ratio in 1820". This is counter-intuitive from a perspective that sees initial technological backwardness as providing intrinsically favourable conditions for catch-up due to imitation. It is due, he claims, to the fact that new techniques invented in rich countries are typically profitable to adopt only at the high wages characteristic of these countries. Poor countries can therefore grow not by imitation but only by saving. At first they adopt old technologies previously invented in countries that are now rich but were poor at the time of the invention (he cites the example of sewing machines, developed in the 1850s and still in use in poor countries today). Only after these countries have crawled up the world production function through saving will their wages rise by enough to make it worthwhile adopting technologies that represent genuine technical progress.

This suggests (though Allen does not draw the conclusion explicitly in his 2012 paper $^{2}$ ) that central planning was able to accelerate the process of catch-up by poor countries, in three main ways. First, by mobilizing domestic savings more effectively than the financial systems of market economies. Secondly, by raising the rate of return to the adoption of modern technologies at any given level of real wages through infrastructure investments (such as in transport and energy) that reduce technical inefficiencies in production and increase the effective size of markets. And finally, by raising real wages through directed investment in human capital.

In this perspective, the legacy of central planning depends on where a country was in the industrialisation or catching-up process at the time it adopted planning, and on the counterfactual - what would have happened had the country not adopted planning? For countries that were already relatively rich and largely industrialised at the time central planning was adopted, the natural counterfactual is that they would have continued to be members of the developed-economy convergence club. The benefits to these countries of high rates of investment in human capital and physical infrastructure would have been relatively

\footnotetext{
${ }^{2}$ However, Allen's (2003) book suggests that Tsarist Russia was missing the institutional prerequisites for successful industrialisation, and that Soviet-type central planning was able to substitute for these gaps.
} 
limited, and the costs of the allocative inefficiencies of central planning substantial. Similarly, in the post-planning transition era, the costs to these countries of inheriting poor economic institutions would be expected to be substantial.

On the other hand, for countries that were very poor and essentially pre-industrial at the time planning was imposed, the counterfactual is not obvious. These countries might have industrialised anyway if their savings rates had been sufficiently high, or they might have remained members of the poor-country (non-) convergence club. ${ }^{3}$ Under the first counterfactual, the legacy of central planning would have been very costly, just as it was for the relatively rich countries that adopted planning. Under the second counterfactual, the legacy of central planning could actually be beneficial, so long as the industrialisation under central planning was not reversed after its removal; furthermore, the poor quality institutions inherited from the planning era would be no worse than the institutions under the counterfactual scenario where the country failed to start sustained catching-up. One way to see which of these two counterfactuals is more likely is to estimate the relationship between initial income and subsequent outcomes separately for countries that adopted planning and for those that remained market economies. A comparison of the two estimated relationships allows us to answer questions such as "Did initially poor countries that adopted planning grow faster than similarly poor countries that remained market economies?" and "Does the answer change if the comparison is between countries that were initially rich instead of initially poor?" This is the exercise we report in this section.

Countries adopted Soviet-style planning at two points in the 20th century. The first group consists of the early adopters: now-independent countries that were part of the Soviet Union when the basic structures of central planning were introduced by Stalin in 1928. The second group of late adopters were countries in Eastern Europe (including 4 countries that were also formally incorporated into the Soviet Union), where socialist planning was imported or imposed following the Second World War. Because of the disruptions of the two world wars, we choose 1913 and 1937 as our pre-planning comparison years for the early and late adopters, respectively. Furthermore, we undertake the comparison separately for each group of countries. Given that the early adopters and the late adopters were exposed to central planning for different periods of time, pooling them for the purposes of making a single comparison is problematic. In addition, we do not want to be committed to a view about the comparability of real incomes measured in 1913 with those measured in 1937. We also do not wish our comparisons to depend on assumptions about whether the more important factor in determining catch-up potential is the absolute level of income (Allen) or the distance to the technological frontier (Gomulka, Good \& $\mathrm{Ma}$ ). For all of these reasons we compare each group of adopters with a comparator group of similar incomes in the same initial year, and look separately, for early and late adopters, at whether relative performance depended on the initial level of income.

Both groups of countries were quite heterogeneous in terms of level of development prior to the adoption of planning. The group of early adopters includes countries such as Russia where industrialisation had already started, and the Central Asian countries, which were extremely poor and essentially still pre-industrial agricultural/nomadic societies. The late adopters were more heterogeneous still, ranging from the industrialised Czech Republic (then part of Czechoslovakia) to very poor and still agricultural Balkan countries. It is this cross-sectional variation in initial income in both groups of countries that enables us to answer the question posed above, namely, how did the impact of adopting planning depend on the initial level of development?

We use long-run cross-country data on GDP per capita to examine both the effect of exposure to planning and its abandonment on comparative development. Our data for 1913 and 1937 derive from Maddison (2009) and are presented in Tables 1a and 1b. Maddison's estimates do not disaggregate the then Russian Empire, USSR, Yugoslavia or Czechoslovakia, ${ }^{4}$ so our figures for the initial years include a large number of estimates; full details are in Appendix A.1. The general picture and results, however, are not very sensitive to the assumptions used.

When looking at both early and late adopters we use two sets of comparator countries that did not adopt planning. The first, larger set includes all countries in Maddison's database in the base year (1913 or 1937) with a level of GDP that is no higher than $20 \%$ above that of the richest country in the group that adopted planning (in 1913, Russia; in 1937, Estonia and Latvia). The second set is a subset of the first and its composition is motivated by the geographical patterns in convergence clubs: we include only countries in Europe and Western, Central and Southern Asia (EWCSA).

The results are presented in two sets of scatterplots, one for the early adopters and one for the late adopters (Fig. 1). In all cases, the horizontal axis is log GDP per capita in the base year (1913 or 1937). The vertical axis is the outcome - the level of development, proxied by GDP per capita - at the very end of the planning era, in 1988, and also after nearly two decades of transition, in 2008. Countries that adopted planning are in red upper-case letters; comparator EWCSA countries are in blue upper-case letters; and comparator countries from elsewhere in the world are in blue lower-case letters. The scatterplots include regression lines corresponding to the three country samples (unbroken lines for countries that experienced planning, dashed lines for all comparators, and dashed-dotted lines for EWCSA comparators only).

The scatterplots clearly suggest the legacy of planning is quite different for the countries that were relatively poor when planning was adopted as compared with those that were relatively rich when planning was adopted. By 1988, the very poorest adopters of planning were as rich, or richer, than the countries that had similar levels of income in 1913 and 1937. The richest adopters of planning, by contrast, were no better off, or poorer, than their comparators. This pattern did not disappear with the abandonment of planning: it is still apparent in the levels of income of planned economies and their capitalist (or market economy) comparators in 2008.

The differences between the estimated regression lines in Fig. 1 can be tested formally by estimating a simple linear regression:

$$
\ln \left(G D P_{t 2}\right)=\beta_{0}+\beta_{1} P L A N_{i}+\beta_{2} \ln \left(G D P_{t 1}\right)+\beta_{3}\left[P L A N_{i} * \ln \left(G D P_{t 1}\right)\right]+e_{i},
$$

\footnotetext{
${ }^{3}$ See Allen (2003, chapter 2) for a discussion of the possible counterfactuals for the case of Soviet industrialisation.

4 Though Broadberry and Klein (2008) do provide a separate estimate for Russia in 1913 which we make use of; see Appendix Notes A1.
} 
Table 1a

GDP per capita in central planning: early adopters and comparators.

\begin{tabular}{|c|c|c|c|c|}
\hline Country & Code & 1913 & 1988 & 2008 \\
\hline \multicolumn{5}{|l|}{ Early adopters } \\
\hline Armenia & ARM & 1669 & 3154 & 5615 \\
\hline Azerbaijan & AZE & 1669 & 6075 & 8024 \\
\hline Belarus & BLR & 2135 & 6669 & 11,747 \\
\hline Georgia & GEO & 1669 & 7780 & 4516 \\
\hline Kazakhstan & $\mathrm{KAZ}$ & 925 & 7219 & 10,469 \\
\hline Kyrgyz Republic & KGZ & 925 & 2395 & 2043 \\
\hline Russian Federation & RUS & 2135 & 13,066 & 14,767 \\
\hline Tajikistan & TJK & 925 & 3363 & 1781 \\
\hline Turkmenistan & TKM & 925 & 4098 & 6326 \\
\hline Ukraine & UKR & 2135 & 8348 & 6721 \\
\hline Uzbekistan & UZB & 1376 & 2004 & 2455 \\
\hline \multicolumn{5}{|c|}{ Comparators, Europe \& West/Central/South Asia } \\
\hline Bangladesh & BGD & 925 & 723 & 1356 \\
\hline Greece & GRC & 2190 & 17,045 & 26,900 \\
\hline India & IND & 925 & 1159 & 2781 \\
\hline Iran, Islamic Rep. & IRN & 1376 & 5440 & 10,398 \\
\hline Iraq & IRQ & 1376 & 6478 & 3560 \\
\hline Jordan & JOR & 1376 & 4051 & 5108 \\
\hline Lebanon & LBN & 1857 & 8044 & 11,017 \\
\hline Nepal & NPL & 742 & 682 & 1021 \\
\hline Pakistan & PAK & 925 & 1569 & 2317 \\
\hline Portugal & PRT & 1721 & 14,625 & 21,962 \\
\hline Sri Lanka & LKA & 1698 & 1877 & 4150 \\
\hline Syrian Arab Republic & SYR & 1858 & 3263 & 4512 \\
\hline Turkey & TUR & 1669 & 7642 & 12,406 \\
\hline \multicolumn{5}{|l|}{ Comparators, Other } \\
\hline Algeria & DZA & 1601 & 6213 & 7367 \\
\hline Brazil & BRA & 1116 & 7519 & 9583 \\
\hline Colombia & COL & 1701 & 5784 & 8250 \\
\hline Egypt, Arab Rep. & EGY & 1241 & 3047 & 5216 \\
\hline Ghana & GHA & 1074 & 882 & 1380 \\
\hline Hong Kong SAR, China & HKG & 1760 & 22,617 & 40,579 \\
\hline Indonesia & IDN & 1203 & 1749 & 3570 \\
\hline Jamaica & JAM & 837 & 5388 & 7344 \\
\hline Japan & JPN & 1908 & 23,665 & 31,307 \\
\hline Korea, Rep. & KOR & 1196 & 9977 & 25,517 \\
\hline Malaysia & MYS & 1239 & 5884 & 12,930 \\
\hline Mexico & MEX & 2383 & 9497 & 12,932 \\
\hline Morocco & MAR & 977 & 2625 & 3973 \\
\hline Myanmar & MMR & 943 & 1042 & 4275 \\
\hline Peru & PER & 1421 & 5573 & 7967 \\
\hline Philippines & PHL & 1360 & 2453 & 3382 \\
\hline Singapore & SGP & 1760 & 22,187 & 47,995 \\
\hline South Africa & $\mathrm{ZAF}$ & 2204 & 8154 & 9602 \\
\hline Taiwan & TWN & 1007 & 12,544 & 30,476 \\
\hline Thailand & THA & 1157 & 3251 & 7378 \\
\hline Tunisia & TUN & 1215 & 3797 & 7357 \\
\hline Venezuela, RB & VEN & 1519 & 10,311 & 11,756 \\
\hline
\end{tabular}

where $\operatorname{PLAN}_{i}$ is a dummy variable taking the value 1 if the country adopted central planning and $t 1$ and $t 2$ refer to the initial reference year and the end year, respectively. The key difference between this formulation and that reported by Good and Ma (1999) is the inclusion of the interaction term $\beta_{3}\left[P L A N_{i}{ }^{*} \ln \left(G D P_{t 1}\right)\right]$. Good and Ma are concerned with the differential growth performance between the countries of Central and Eastern Europe and their comparator countries, and they employ a specification with a catching-up effect common to planned and market economies; in our Eq. (1) above, this is equivalent to focusing on $\beta_{1}$ and assuming $\beta_{3}=0$. Our more general specification in effect allows for a wider range of possibilities: for instance, poor countries with central planning could initially grow more quickly than similarly poor market economies (converge in income towards the developed market economies), and at the same time richer (less poor) planned countries could grow more slowly than their market economy comparators. ${ }^{5}$

\footnotetext{
${ }^{5}$ More precisely, Good and Ma estimate a model where the dependent variable is the rate of growth and the explanatory variables include a regional dummy for Central and Eastern Europe (their focus) and a measure of the productivity gap between the country and the technological leader (taken to be the US). Because all the observations in our separate early- and late-adopter estimations share a common starting year, our use of the level of GDP per capita in the initial year corresponds to the measure of the productivity gap in their formulation. Other differences are that Good and Ma consider a narrower range of counties - Central and Eastern Europe vs. other European countries - and a wider range of time periods, including those prior to the planning experience.
} 
Table 1b

GDP per capita in central planning: late adopters and comparators.

\begin{tabular}{|c|c|c|c|c|}
\hline Country & Code & 1937 & 1988 & 2008 \\
\hline \multicolumn{5}{|l|}{ Late adopters } \\
\hline Albania & ALB & 1578 & 4058 & 7223 \\
\hline Bosnia and Herzegovina & $\mathrm{BIH}$ & 1391 & 2797 & 5382 \\
\hline Bulgaria & BGR & 2156 & 8323 & 12,005 \\
\hline Croatia & HRV & 1947 & 14,446 & 17,317 \\
\hline Czech Republic & CZE & 4622 & 16,510 & 23,223 \\
\hline Estonia & EST & 4735 & 10,641 & 18,646 \\
\hline Hungary & HUN & 3499 & 12,551 & 17,442 \\
\hline Latvia & LVA & 4735 & 10,381 & 15,662 \\
\hline Lithuania & LTU & 2636 & 12,986 & 17,616 \\
\hline Macedonia, FYR & MKD & 1202 & 9290 & 8786 \\
\hline Moldova & MDA & 1659 & 4516 & 2768 \\
\hline Poland & POL & 2636 & 9251 & 16,455 \\
\hline Romania & ROU & 1659 & 8896 & 11,793 \\
\hline Serbia and Montenegro & SAM & 1515 & 10,474 & 7130 \\
\hline Slovak Republic & SVK & 1942 & 12,647 & 20,515 \\
\hline Slovenia & SVN & 3184 & 17,986 & 27,197 \\
\hline \multicolumn{5}{|c|}{ Comparators, Europe \& West/Central/South Asia } \\
\hline Austria & AUT & 4343 & 24,111 & 36,193 \\
\hline Finland & FIN & 4735 & 22,064 & 33,626 \\
\hline Greece & GRC & 3810 & 17,045 & 26,900 \\
\hline India & IND & 930 & 1159 & 2781 \\
\hline Ireland & IRL & 4069 & 15,246 & 38,955 \\
\hline Italy & ITA & 4568 & 22,569 & 28,168 \\
\hline Norway & NOR & 5770 & 31,440 & 48,557 \\
\hline Pakistan & PAK & 930 & 1569 & 2317 \\
\hline Portugal & PRT & 2418 & 14,625 & 21,962 \\
\hline Spain & ESP & 2488 & 18,240 & 28,340 \\
\hline Sri Lanka & LKA & 1715 & 1877 & 4150 \\
\hline Turkey & TUR & 2219 & 7642 & 12,406 \\
\hline \multicolumn{5}{|l|}{ Comparators, Other } \\
\hline Argentina & ARG & 5677 & 8499 & 13,276 \\
\hline Brazil & BRA & 1720 & 7519 & 9583 \\
\hline Chile & $\mathrm{CHL}$ & 4378 & 5948 & 13,394 \\
\hline Colombia & COL & 2409 & 5784 & 8250 \\
\hline Costa Rica & CRI & 2479 & 6016 & 10,367 \\
\hline Ecuador & ECU & 1790 & 5565 & 7251 \\
\hline El Salvador & SLV & 1465 & 3577 & 6275 \\
\hline Guatemala & GTM & 3036 & 3254 & 4365 \\
\hline Honduras & HND & 1463 & 2695 & 3636 \\
\hline Indonesia & IDN & 1540 & 1749 & 3570 \\
\hline Jamaica & JAM & 1338 & 5388 & 7344 \\
\hline Japan & JPN & 3186 & 23,665 & 31,307 \\
\hline Korea, Rep. & KOR & 2149 & 9977 & 25,517 \\
\hline Malaysia & MYS & 1801 & 5884 & 12,930 \\
\hline Mexico & MEX & 2471 & 9497 & 12,932 \\
\hline Myanmar & MMR & 1086 & 1042 & 4275 \\
\hline Nicaragua & NIC & 1449 & 2006 & 2494 \\
\hline Paraguay & PRY & 2606 & 3872 & 4352 \\
\hline Peru & PER & 2650 & 5573 & 7967 \\
\hline Philippines & PHL & 1965 & 2453 & 3382 \\
\hline Taiwan & TWN & 1732 & 12,544 & 30,476 \\
\hline Uruguay & URY & 4764 & 7296 & 11,675 \\
\hline
\end{tabular}

Notes to Tables $1 \mathrm{a}$ and $1 \mathrm{~b}$.

All figures are in US \$2005 international dollars. 1913 and 1937 GDP per capita are from Maddison (2009) in US \$1990, converted to US \$2005 using US GDP in 1990 from Maddison (in \$1990) and World Bank (WB) World Development Indicators (WDI) (in \$2005), except for selected planned economies, which are from Broadberry and Klein (2008), also in US \$1990 and converted to US \$2005. 1988 and 2008 derive from World Bank WDI, in turn derived from the ICP Project. Various figures for 1913, 1937 and 1988 are estimates by the authors. See Appendix A.1 for details.

The 1913 market economy sample consists of all market economies in Maddison with an estimated GDP per capita in 1913 of no more than $20 \%$ more (in log terms) than the richest planned economy (Russia, source Broadberry-Klein; see Appendix for further details). China was also excluded. No lower limit was used. The 1937 market economy sample consists of all market economies in Maddison with an estimated GDP per capita in 1937 of at most 20\% more (in log terms) than the richest planned economy (Estonia and Latvia, estimated to have the same GDP per capita as Finland; see Appendix for further details). China was also excluded. No lower limit was used.

Eq. (1) is estimated using OLS with heteroskedastic-robust standard errors. The results are shown in Table 2a. The estimated $\hat{\beta}_{3}$, the coefficient on the interaction term $\left[\operatorname{PLAN}_{i}{ }^{*} \ln \left(G D P_{t 1}\right)\right]$, is negative in all eight estimations and significantly different from zero in six, suggesting our more general specification is warranted. The finding that $\hat{\beta}_{3}<0$ - visible as the flatter estimated 
relationships for planned economies in Fig. 1 - is evidence that the effect of central planning was significantly more negative the richer the country was before planning was imposed.

We can also use the results of the estimation of Eq. (1) to test the difference in log GDP per capita between planned and market economies at the end date for a range of values $Y$ of initial GDP per capita (Table 2b). In other words, we estimate the difference in value of $\hat{\beta}_{0}+\hat{\beta}_{3} Y$ for the two groups of countries - the vertical distance between the corresponding two regression lines in Fig. 1, measured at a chosen initial income $Y$ - and test its statistical significance. The values $Y$ at which we choose to test the difference correspond to the lowest and highest observed incomes among the countries that would adopt planning in the relevant group of adopters: \$925 and \$2125 per capita in 1913 (early adopters), and \$1200 and \$4750 in 1937 (late adopters). The table shows that in 1988, the poorest countries that adopted planning had, on average, incomes that were $53-102 \%$ higher (in log percentage points) than their comparators, depending on the composition of the comparison (early or late adopters, all comparators or just EWCSA countries); three of these four comparisons are statistically significant. The four comparisons involving the richer adopters show that their incomes in 1988 were, on average, 14-57\% lower than their comparators; two of these comparisons are statistically significant. By 2008, the gap for the poorest adopters had decreased, but the gap for the richest adopters had increased.

In sum: initially poor countries ended planning no worse off, and if anything, better off, than their pre-planning peers; but any advantage was less visible in 2008, after the planning collapse and the partial and unevenly spread recovery. Initially rich countries ended planning no better off, and if anything, worse off, than their pre-planning peers; and this disadvantage was still more visible in 2008.

This pattern is consistent with the view that central planning could generate rapid growth in initially poor and unindustrialised countries via the mobilisation of resources and high rates of investment in physical and human capital and public infrastructure. When planning was abandoned, poorer countries should therefore have been relatively well-endowed with physical infrastructure and human capital compared to market economies with similar incomes. In the already-industrialised,

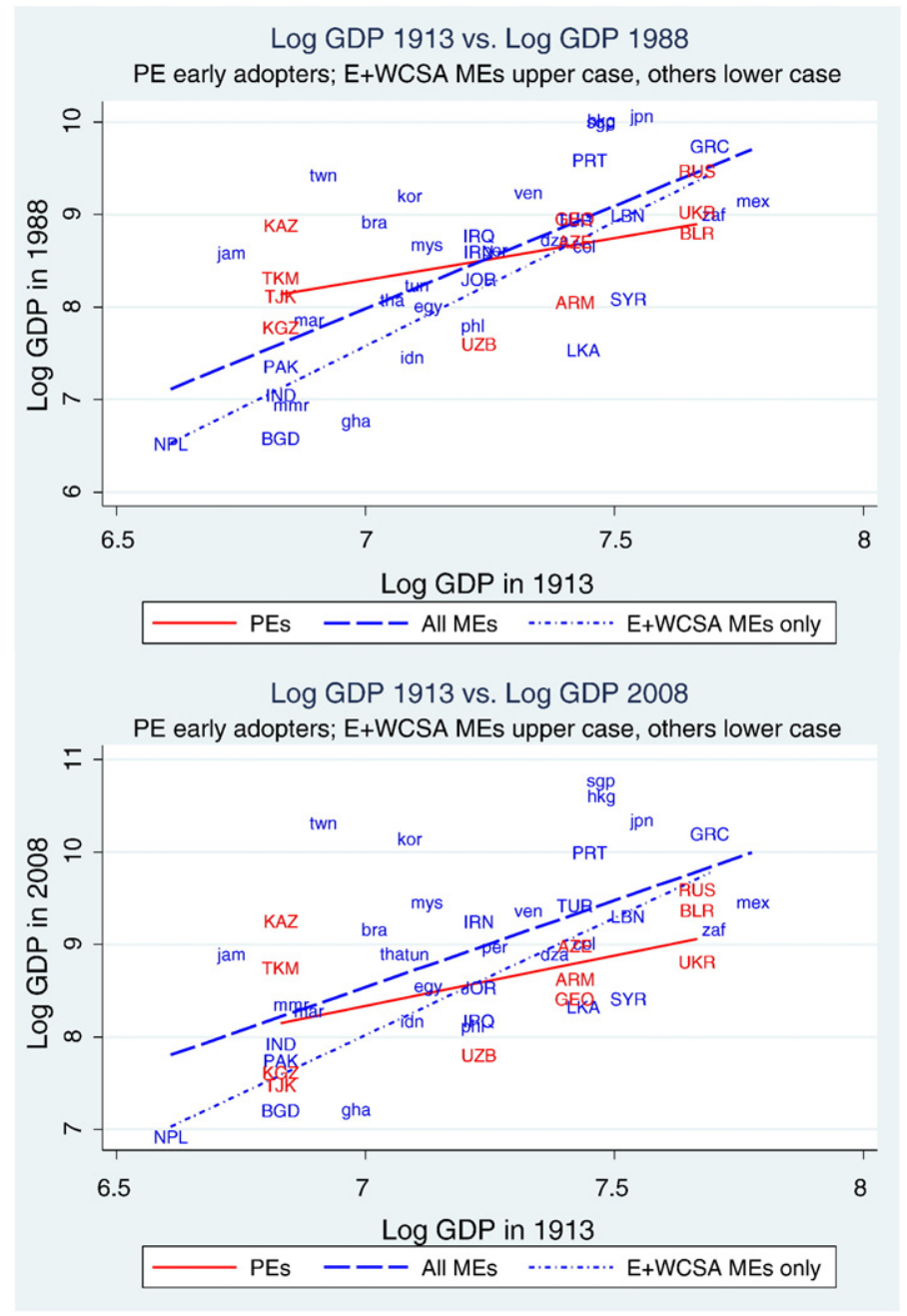

Fig. 1. Long-run growth for economies exposed and not exposed to Soviet-style planning. 


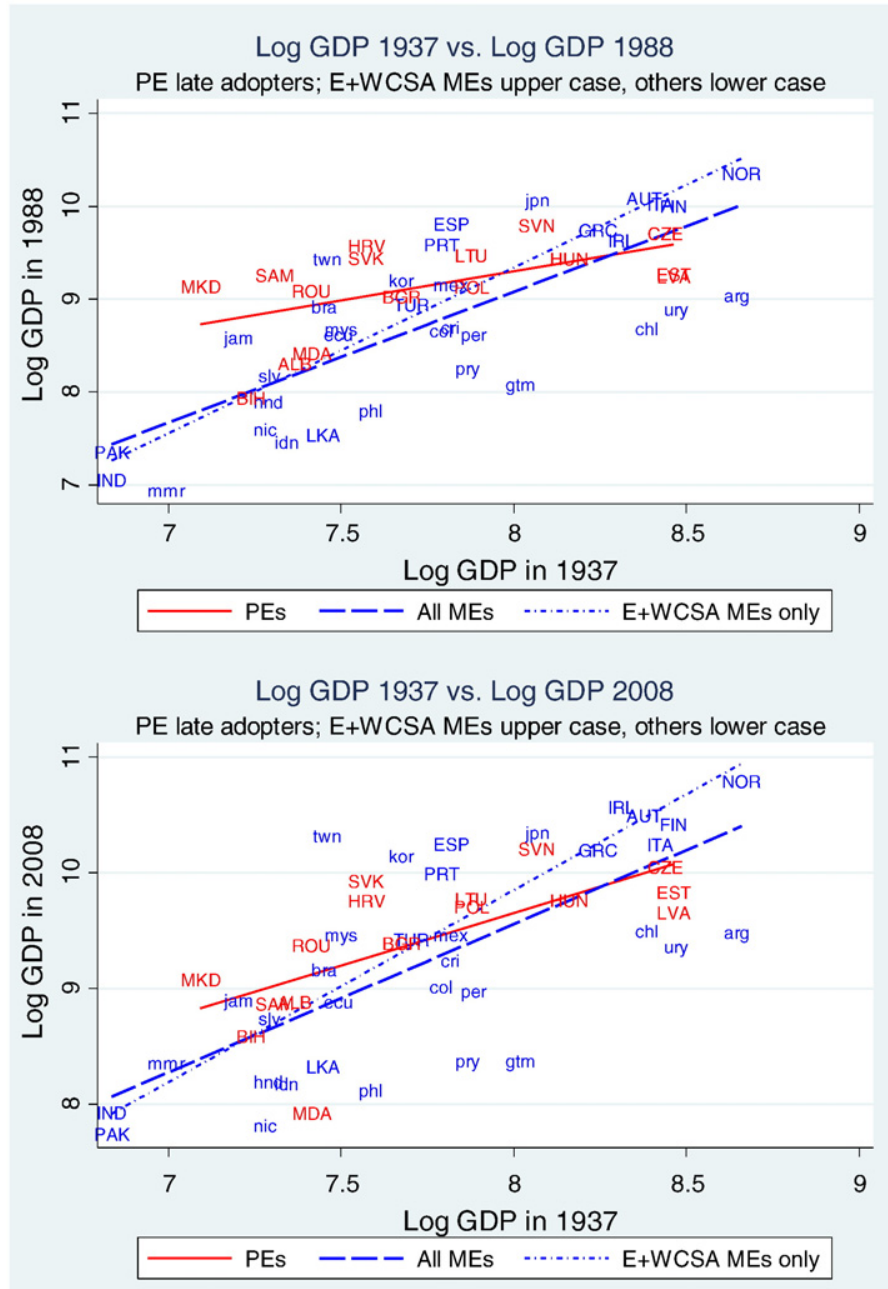

Fig. 1 (continued).

richer countries that adopted planning, the additional mobilisation of resources had fewer payoffs. The legacy of weak institutions would therefore have weighed more heavily on these richer countries.

In the next section we consider the aggregate evidence from 1988 and from 2008 for the existence of legacies of physical and human capital, public infrastructure, and economic institutions in the planned economies.

\section{The long shadow of communism: how normal were the planned economies?}

In this section we compare the level of physical infrastructure and human capital, and the quality of a range of public inputs and market institutions believed to be important for the growth of firms, between planned and market economies at the end of the planning period and in the second decade of transition to the market economy. Relative to their GDP per capita peers that had not experienced planning, did the legacy of decades with non-market allocations still affect the quality of market institutions after more than a decade and a half of transition to the market economy? This set of cross-country comparisons helps clarify whether planning left traces of the kind suggested by the hypothesis of forced investment, how long they lasted and how quickly deficits in market institutions were overcome.

We present scatterplots of public inputs in planned and market economies against GDP per capita, and again fit simple linear regressions to these data using OLS. We estimate the gaps at a low and high level of GDP per capita, defined as, respectively, the level of the poorest planned economy in the sample and at the level of the richest planned economy in the sample, from a simple cross-country equation of the form:

$$
\bar{B}_{j}=\beta_{0}+\beta_{1} P L A N_{i}+\beta_{2} \ln \left(G D P_{i}\right)+\beta_{3}\left[P L A N_{i} * \ln \left(G D P_{i}\right)\right]+e_{i},
$$

where $\bar{B}_{j}$ is a measure of the public input in country $j$. 
Table 2a

The impact of planning on long-run development: regression estimates for Table 2b and Fig. 1.

\begin{tabular}{|c|c|c|c|c|}
\hline & Full sample, 1913-1988 & EWCSA only, 1913-1988 & Full sample 1937-1988 & EWCSA only, 1937-1988 \\
\hline \multirow[t]{2}{*}{$\operatorname{Ln}\left(\mathrm{GDP}_{\mathrm{t} 1}\right)$} & $2.22^{* * *}$ & $2.68^{* * *}$ & $1.41^{* * *}$ & $1.78^{* * *}$ \\
\hline & $(0.46)$ & $(0.40)$ & $(0.20)$ & $(0.13)$ \\
\hline \multirow{2}{*}{ PLAN* $\operatorname{Ln}\left(\mathrm{GDP}_{\mathrm{t} 1}\right)$} & $-1.31^{* *}$ & $-1.77^{* * *}$ & $-0.78^{* *}$ & $-1.16^{* * *}$ \\
\hline & $(0.58)$ & $(0.55)$ & $(0.32)$ & $(0.28)$ \\
\hline \multirow[t]{2}{*}{ PLAN } & $9.50^{* *}$ & $13.11^{* * *}$ & $6.48^{* *}$ & $9.20^{* * *}$ \\
\hline & $(4.25)$ & $(3.95)$ & $(2.486)$ & $(2.27)$ \\
\hline \multirow[t]{2}{*}{ Constant } & $-7.55^{* *}$ & $-11.17^{* * *}$ & -2.19 & $-4.92^{* * *}$ \\
\hline & (3.32) & $(2.82)$ & $(1.58)$ & (1.09) \\
\hline R-squared & 0.44 & 0.65 & 0.57 & 0.76 \\
\hline \multirow[t]{2}{*}{$\mathrm{N}$} & 46 & 24 & 50 & 28 \\
\hline & Full sample, 1913-2008 & EWCSA only, 1913-2008 & Full sample 1937-2008 & EWCSA only, 1937-2008 \\
\hline \multirow[t]{2}{*}{$\operatorname{Ln}\left(G P_{t 1}\right)$} & $1.88^{* * *}$ & $2.53^{* * *}$ & $1.28^{* * *}$ & $1.66^{* * *}$ \\
\hline & $(0.47)$ & $(0.39)$ & $(0.19)$ & $(0.11)$ \\
\hline \multirow[t]{2}{*}{ PLAN* $\operatorname{Ln}\left(\mathrm{GDP}_{\mathrm{t} 1}\right)$} & -0.79 & $-1.45^{*}$ & -0.37 & $-0.75^{* * *}$ \\
\hline & $(0.74)$ & $(0.71)$ & $(0.29)$ & $(0.25)$ \\
\hline \multirow[t]{2}{*}{ PLAN } & 5.33 & $10.46^{*}$ & 3.04 & $5.77^{* * *}$ \\
\hline & $(5.42)$ & $(5.18)$ & $(2.27)$ & $(2.04)$ \\
\hline \multirow[t]{2}{*}{ Constant } & -4.59 & $-9.72^{* * *}$ & -0.69 & $-3.42^{* * *}$ \\
\hline & (3.43) & $(2.74)$ & $(1.43)$ & $(0.90)$ \\
\hline R-squared & 0.35 & 0.60 & 0.51 & 0.78 \\
\hline $\mathrm{N}$ & 46 & 24 & 50 & 28 \\
\hline
\end{tabular}

${ }^{*} \mathrm{p}<0.10,{ }^{* *} \mathrm{p}<0.05,{ }^{* * *} \mathrm{p}<0.01$.

Heteroskedastic-robust standard errors in parentheses.

For physical infrastructure and education, quantitative indicators are available as proxy measures of the supply of public inputs at country level at the end of central planning. In Fig. 2 we compare the endowments of physical infrastructure and enrolment in secondary education in the former planned economies and market economies when communism collapsed. The indicators are electricity generation, railway track, telephone mainlines, and secondary school enrolment (\% of cohort). Comparisons between planned and market economies are reported in Table 3 for a low and high level of GDP per capita. In all cases the provision in poor planned economies in 1988 was higher than was the case for market economies. These endowments of physical and human capital persisted from the planning era into transition in the poorer countries: in 2008, the poorer formerly planned economies had substantially more of all four types of inputs than their market economy comparators. The richer planned economies, however, were less well-endowed versus their market comparators: in 1988, they had more railway lines and modestly more human capital, but no more electricity generation capacity and fewer telephone lines; and by 2008, if anything, less human capital than their market economy comparators.

Table 2b

Regression-based estimates of the impact of planning on long-run development.

\begin{tabular}{|c|c|c|c|c|c|c|c|}
\hline Ref year & End year & Sample & $\$ 925$ & $\$ 1200$ & $\$ 2125$ & $\$ 4750$ & $\begin{array}{c}\text { \#Obs: } \\
\text { PEs/MEs/All }\end{array}$ \\
\hline 1913 & 1988 & All & 0.53 & & $-0.56^{*}$ & & $11 / 35 / 46$ \\
\hline 1913 & 1988 & E \& WCSA & $1.02^{* *}$ & & -0.46 & & $11 / 13 / 24$ \\
\hline 1937 & 1988 & All & & $0.93^{* *}$ & & -0.14 & $16 / 34 / 50$ \\
\hline 1937 & 1988 & E \& WCSA & & $1.01^{* *}$ & & $-0.57^{* *}$ & $16 / 12 / 28$ \\
\hline 1913 & 2008 & All & -0.07 & & $-0.72^{* *}$ & & $11 / 35 / 46$ \\
\hline 1913 & 2008 & E \& WCSA & 0.56 & & $-0.63^{*}$ & & $11 / 13 / 24$ \\
\hline 1937 & 2008 & All & & 0.44 & & -0.07 & $16 / 34 / 50$ \\
\hline 1937 & 2008 & E \& WCSA & & $0.49^{*}$ & & $-0.54^{* *}$ & $16 / 12 / 28$ \\
\hline
\end{tabular}

${ }^{*}=\operatorname{sig}$ at $10 \%$

$* *=\operatorname{sig}$ at $5 \%$.

Notes to Tables $2 \mathrm{a}$ and $2 \mathrm{~b}$.

The values chosen for $\boldsymbol{Y}$ correspond to the min and max GDP per capita at PPP in 2005 \$US for the early and late planned economy adopters.

Min planned economy GDP per capita in 1913: $\$ 925$ (Kazakhstan, Kyrgyzstan, Tajikistan, Turkmenistan, calibrated to Maddison estimate of India).

Max planned economy GDP per capita in 1913: \$2135 (Russia, source Broadberry-Klein. NB: Maddison estimate for total FSU in 1913=\$2047).

Min planned economy GDP per capita in 1937: \$1202 (Macedonia, based on Maddison 1937 estimate for Yugoslavia and 1953 relative social product per head for the separate Yugoslav republics).

Max planned economy GDP per capita in 1937: \$4735 (Estonia and Latvia, calibrated to Maddison estimate for Finland and NEBI yearbook assessment of prewar living standards).

E \& WCSA = market economy sample includes Europe and West/Central/South Asia only.

See Appendix A.1 for notes on the data. 
In short, according to the aggregate indicator data, formerly planned economies, especially poor ones where industrialisation took place under planning, entered transition with higher levels of physical infrastructure and human capital than was characteristic of market economies at a similar level of development. To the extent that GDP per capita was overstated in the planned economies, these positive infrastructure endowment gaps were even larger.

An important caveat to these findings is that the aggregate indicators do not provide an accurate measure of the flow of services from public inputs. This is especially troubling in interpreting the post-communist experience. For example, it is clear from Fig. 2 that railway networks throughout the transition period were very extensive in the former planned economies relative to their market economy peers - this was true right across the GDP per capita distribution. However, these networks were geared to the transportation of freight between enterprises according to the Plan. The supply-chains linked by the rail network often
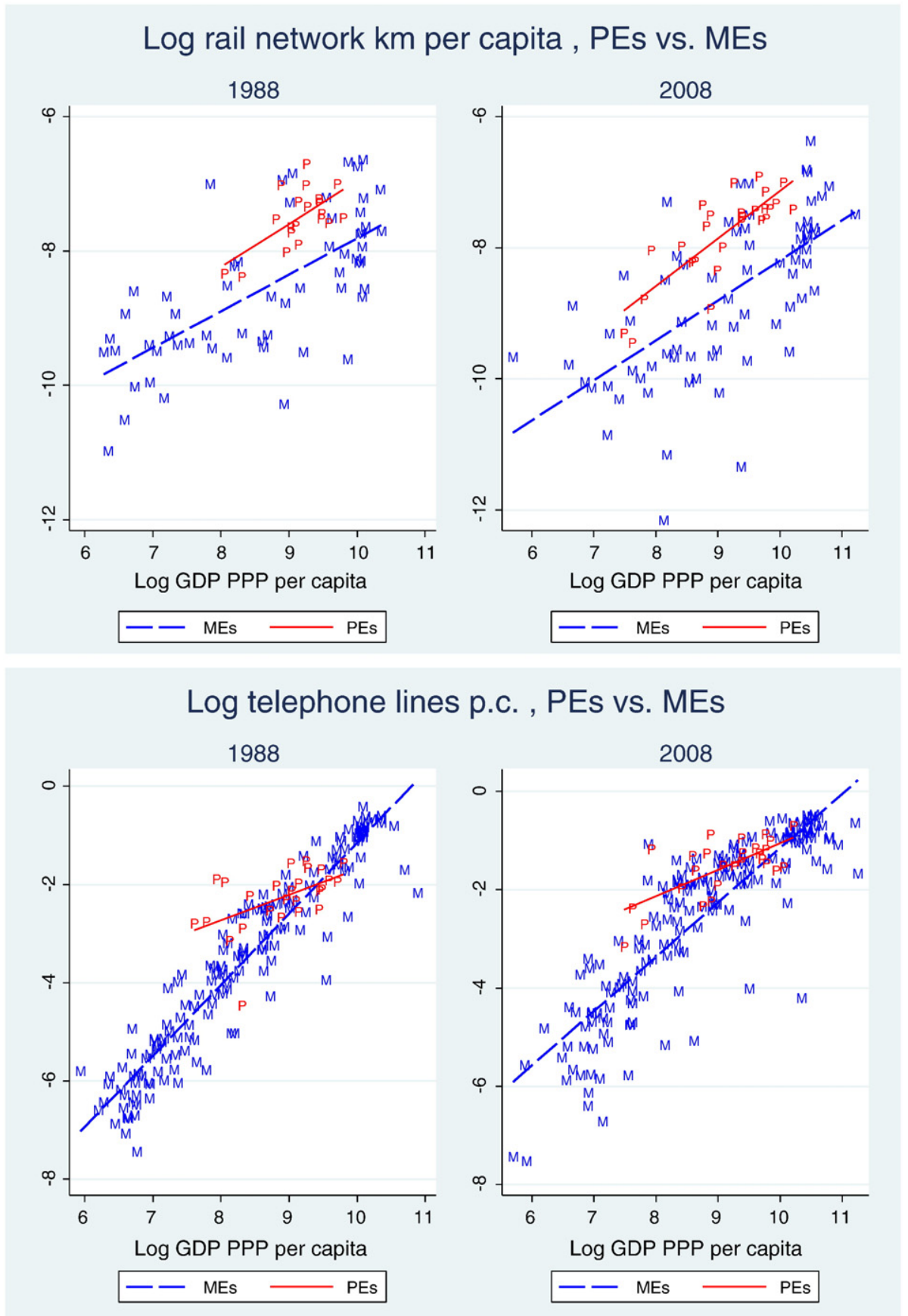

Fig. 2. Levels of physical infrastructure and schooling - planned and market economies, 1988 and 2008. Source: World Bank, World Development Indicators, except electricity generation capacity, which is from the US Energy Information Administration. 

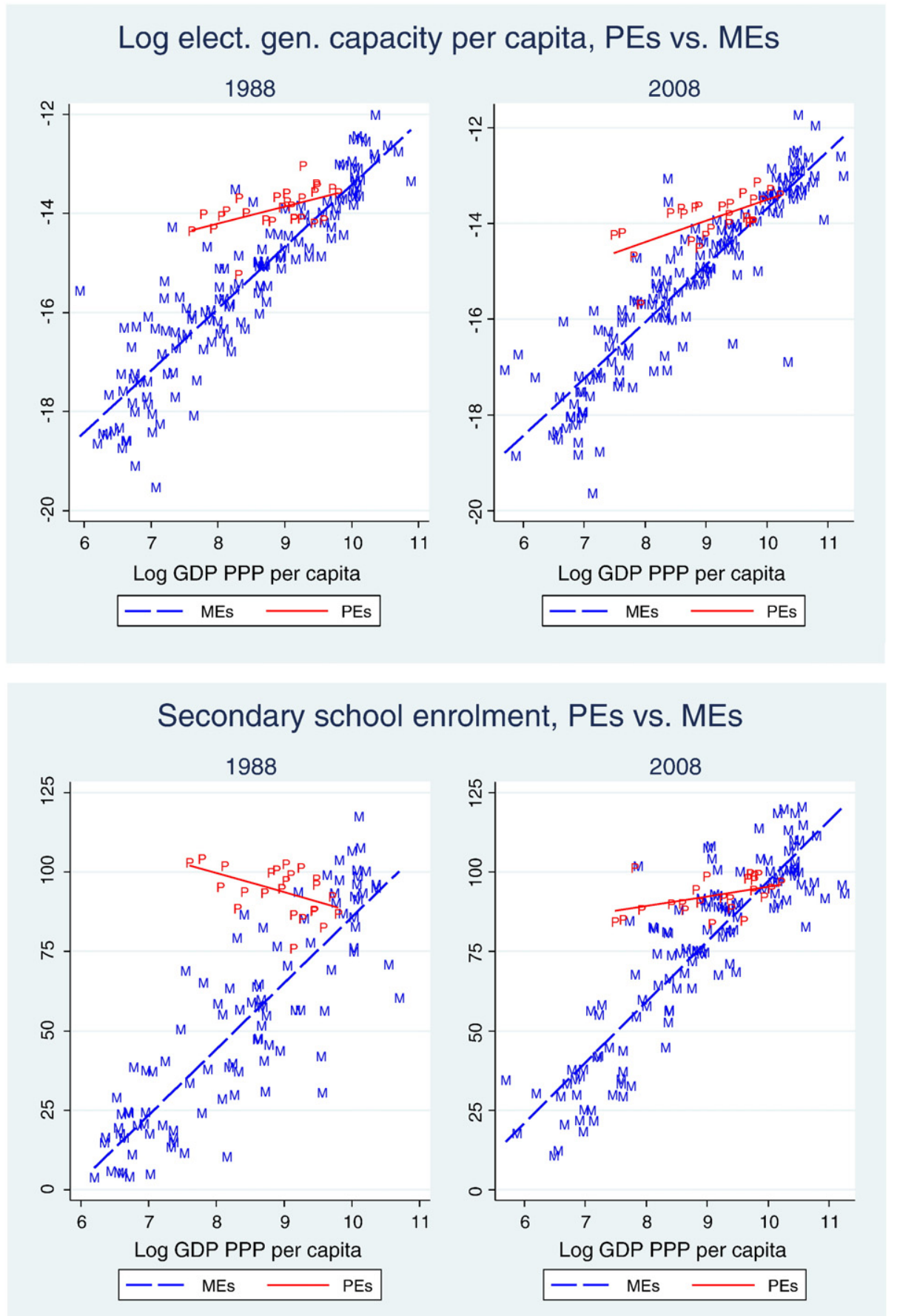

olment, PEs vs. MEs

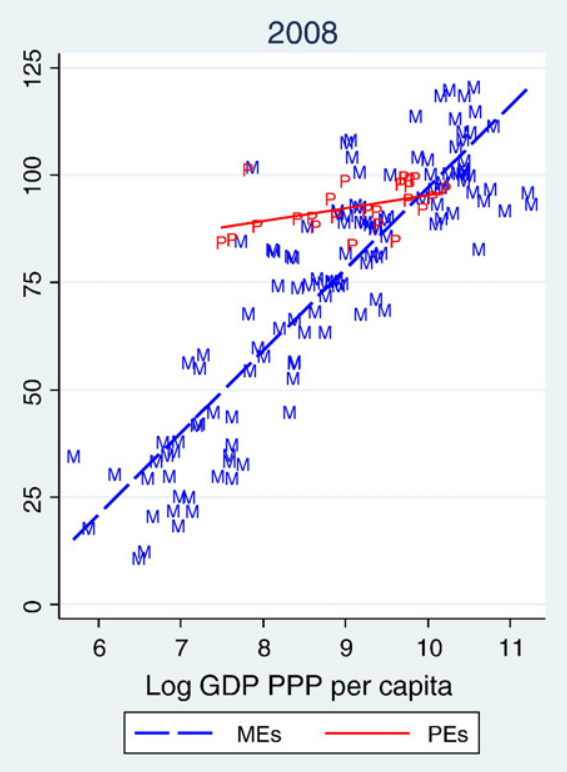

Fig. 2 (continued).

collapsed when planning and the trading arrangements in the CMEA were abandoned and the value of the remaining rail network to firms in the market economy is almost certainly not well-measured by the kilometres of track per capita (see EBRD, 1996). Similarly, it is not straightforward to measure the value of human capital acquired under the central planning regime. We return to this measurement problem shortly.

Although there is an extensive literature describing shortcomings in market-economy institutions at the outset of transition (e.g. Roland, 2000, Svejnar, 2002), quantitative indicators of gaps in institutional inputs are more difficult to find. There are a number of country-level proxy indicators of the business environment, each with a somewhat different focus. Examples that have 
Table 3

Planned/Market economy gaps in stocks of physical infrastructure and secondary school enrolment, 1988 and 2008.

\begin{tabular}{|c|c|c|c|c|c|c|c|c|c|}
\hline Physical infrastructure and human capital & Low income PE \$ & Market & Planned & Difference & High income PE \$ & Market & Planned & Difference & Countries \\
\hline \multicolumn{10}{|l|}{ End of planning: 1988} \\
\hline Log rail route km per capita & 3154 & -8.87 & -8.20 & $0.66^{* *}$ & 17,986 & -7.92 & -7.09 & $0.83^{* *}$ & 79 \\
\hline Log tel. lines per 10,000 pop & 2004 & -4.62 & -2.93 & $1.69^{* *}$ & 17,986 & -1.44 & -1.79 & $-0.35^{*}$ & 185 \\
\hline Log electr. gen. cap. GW per capita & 2004 & -16.42 & -14.34 & $2.08^{* *}$ & 17,986 & -13.67 & -13.59 & 0.08 & 165 \\
\hline $\begin{array}{l}\text { Percent enrolment in secondary school } \\
\text { After two decades of transition: } 2008\end{array}$ & 2004 & 36.02 & 101.97 & $65.95^{* *}$ & 17,986 & 81.57 & 88.86 & $7.29^{*}$ & 122 \\
\hline Log rail route km per capita & 1781 & -9.73 & -8.96 & $0.77^{* *}$ & 27,197 & -8.07 & -6.98 & $1.09^{* *}$ & 100 \\
\hline Log tel. lines per 10,000 pop & 1781 & -3.93 & -2.39 & $1.54^{* *}$ & 27,197 & -0.92 & -0.91 & 0.01 & 199 \\
\hline Log electr. gen. cap. GW per capita & 1781 & -16.67 & -14.62 & $2.06^{* *}$ & 27,197 & -13.43 & -13.41 & 0.02 & 178 \\
\hline Percent enrolment in secondary school & 1781 & 49.14 & 87.68 & $38.54^{* *}$ & 27,197 & 101.93 & 95.84 & $-6.09^{*}$ & 152 \\
\hline
\end{tabular}

Source: As for Fig. 1.

$*=$ significant at $5 \%$.

** = significant at $1 \%$.

"Low income PE \$" = GDP per capita in PPP \$2005 of lowest-income planned economy in estimation sample.

"High income PE \$" = GDP per capita in PPP \$2005 of highest-income planned economy in estimation sample.

been widely used in the economics and political science literature are the World Bank's World Governance and Doing Business indicators, and the Economic Freedom indicators produced by the Heritage Foundation and by the Fraser Institute. Appendix Table A1 summarises the nature of the data sources used and the methods by which these four different sets of aggregate indicators are compiled.

Unfortunately data of this kind rarely provide a clear or informative picture. Sometimes this is because measures from different sources tell inconsistent messages. Fig. 3 illustrates, using two aspects of the business environment (trade and corruption), and comparing the results for the three sources where data for the particular aspect are reported. World Bank Governance, Heritage and Fraser produce a rating of the business environment related to corruption (top row of charts in Fig. 3 ). Although the results are very noisy, the patterns are consistent across indicators: formerly planned economies score more poorly than do market ones at similar levels of GDP per capita. Unfortunately, inconsistencies across indicators are also common. Doing Business, Heritage and Fraser all report an indicator related to trade (Fig. 3, lower row of charts). Higher GDP per capita is associated with a better score on the indicator in each case. However, unlike the corruption example, different indicators of the
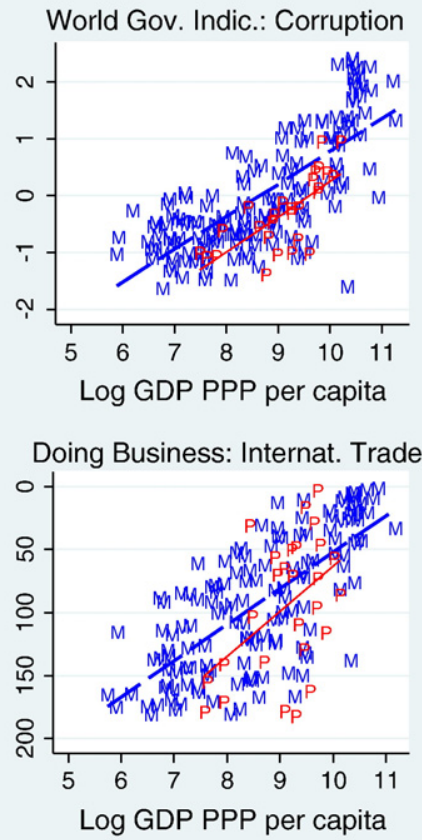
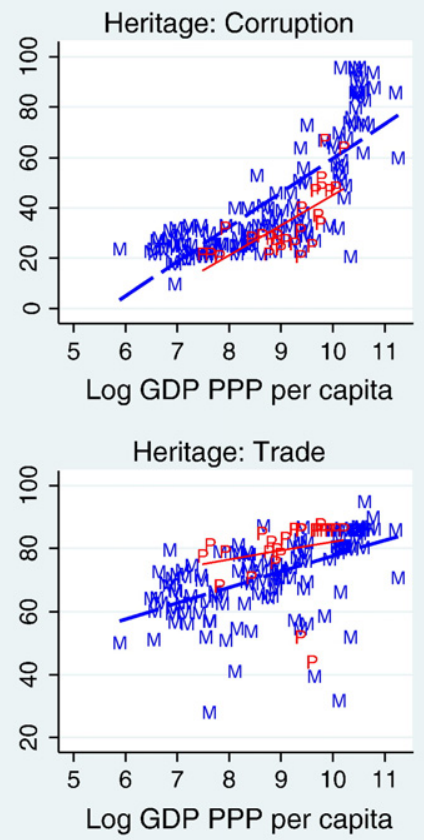

Fraser: Extra Payments/Bribes

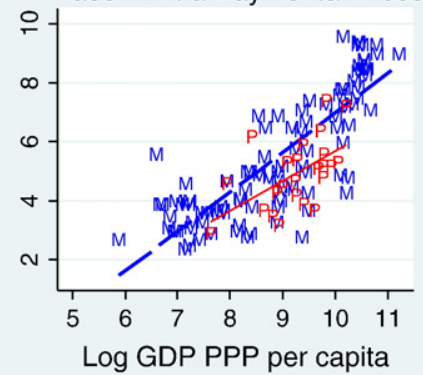

Fraser: Trade

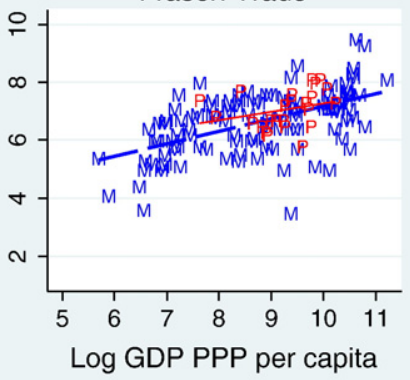

$\mathrm{P}=$ Formerly planned economies

M=Market economies

Fig. 3. Measures of the business environment (corruption and trade) in planned and market economies. Sources: See Table A1. 
environment for engaging in trade point in different directions regarding comparisons between formerly planned and market economies. The Fraser indicator shows no difference between planned and market economies; the Doing Business indicator suggests that the environment for international trade is less good in poor formerly planned economies than in poor market economies; and the Heritage index suggests the opposite. Such examples are not uncommon, and even where the data from different sources are consistent they are often noisy and hard to relate in systematic ways to other aspects of the economies in question.

To summarise: at the end of planning the low-income planned economies look much better endowed with physical infrastructure and human capital than similarly low-income market economies, and this difference has persisted quantitatively as well as qualitatively through 2008. The difference in these endowments in the richer countries that experienced planning was smaller at the end of planning than in their market economy comparators, and smaller still by 2008. However, there are questions about how well these measures capture the value of the flow of services from these public inputs. The picture with respect to market institutions is much less clear still, in large part because the indicators are noisy and sometimes inconsistent.

There is a further caveat to this aggregate evidence. Since the distortions under planning were potentially positive for future growth prospects in relation to infrastructure and education and negative in relation to market institutions, we would like to make comparisons across types of public input between the economies that were exposed to planning and those that were not. This cannot be readily done using aggregate indicators because of the "curse of dimensionality". There are too few countries and too many potential determinants of growth that vary at the country level for us to be able to estimate precisely the different impacts (Durlauf et al., 2005). Even if we can reliably distinguish the quality of such institutions as the rule of law in one country from that in another, this does not say anything about whether problems with the rule of law are more or less of a constraint on private sector growth than are problems with, say, electricity.

In the next section we show how microeconomic data from surveys of firms can be used to address these problems.

\section{Measuring the impact of the external environment on firms using firm-level survey data}

For more than a decade, the EBRD and the World Bank have been conducting surveys of thousands of firms around the world, asking managers inter alia about aspects of the business environment in which their firms operate. The usual approach to employing these survey data to measure the impact of infrastructure, institutions and other public inputs is to estimate a regression in which a measure of firm performance is the dependent variable, and measures of the business environment are included as regressors. A simple example would be a production function estimation in which the dependent variable is firm output and the independent variables are the firm's capital, labour, and what the firm reports about an aspect of the business environment, e.g., whether or not corruption is an important problem. Dethier et al. (2010) provide a survey of this literature. ${ }^{6}$ Commander and Svejnar (2011) and Commander and Nikoloski (2011) analyse formerly planned economies and are the most relevant studies of this kind.

The above approach is problematic for several reasons (Carlin et al., 2006, 2010), the most important of which in our context is again the "curse of dimensionality". Public inputs typically vary primarily at the country level (or regional level in large countries). This means that even with large numbers of firms, the sample size is actually small: because all the firms in a country face the same set of institutions, it is the number of countries rather than the number of firms that drives the effective sample size. The empirical challenges of this approach are therefore effectively the same as those facing studies using aggregate data: there are too few different country experiences, and too many imperfectly measured and correlated indicators, to be able to precisely identify the causal impacts of different public inputs on output and growth.

To understand whether planning left countries with different constraints on growth from their non-planning peers, we therefore employ a new methodology proposed by Carlin et al. $(2006,2010){ }^{7}$ The data come from the business environment surveys conducted by the EBRD and World Bank between 2002 and 2010. ${ }^{8}$ A standard question was asked in which managers were required to evaluate the importance for the operation and growth of their business of a broad range of public inputs. In the context of the formerly planned economies, these data are attractive because they come mainly from small and medium-sized firms, providing a window into the value to these new entrants in the post-planning period of the inherited infrastructure (such as the railway network), and of the emerging market institutions.

The enterprise surveys collect a range of "Subjective Severity" indicators from firms. These are responses to questions about a feature of the business environment faced by the firm, where the question takes the form, "How much of an obstacle is X to the operation and growth of your business?", and the respondent rates the severity on a 5-point scale of 0 ("no obstacle") to 4 ("very severe obstacle"). The dimensions of the external environment asked about and which we refer to as public inputs include the following: telecoms, electricity, transport, skills availability, macroeconomic/political/policy stability, tax administration, customs administration, labour regulation, the court system, corruption and crime. ${ }^{9}$

A simple and intuitive interpretation of the responses to these questions is that these are the firm's assessments of the costs it incurs because of operating in an environment with poor-quality public inputs. In contrast to their use on the right hand side of a

\footnotetext{
${ }^{6}$ Among other studies using an augmented production function approach with the various subsets of the business environment survey data are Beck et al. (2005), Hallward-Driemeier, et al. (2006), Dollar et al. 2005 and Hallward-Driemeier and Aterido, 2009.

7 See also Carlin and Schaffer (2012) for an application of this methodology to firms and the business environment in South Asia.

8 The data and documentation are openly available at http://www.enterprisesurveys.org.

9 Although questions are asked in the survey about tax rates and access to finance, we exclude them from the analysis because they do not have the character of public inputs (Carlin et al. 2010). We also exclude the question about competition since the wording changed substantially over time and surveys.
} 


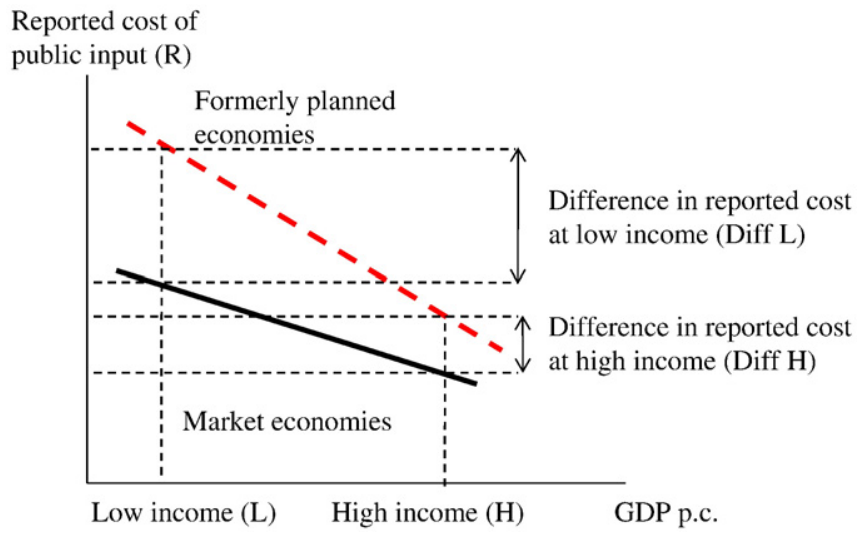

Fig. 4. Framework for using firm-level survey data to measure the shadow costs to firms of their external environment.

production function as proxies for the flows of services from various public inputs, this interpretation (following Carlin et al. 2006, 2010) sees them as shadow prices. The shadow price interpretation rests on the assumption that firms have a notion of the flows of services from the different elements of their business environment, and that their answer puts a value on them in terms of their impact on profitability. If a firm reported, say, the court system as an important obstacle, this can be interpreted as a high shadow price: a relaxation of this constraint via an improved court system would therefore be expected to reduce the shadow price and lead to higher profits and increased output. If most firms in a country report that the court system is an important obstacle, then the high average shadow price allows us to infer that this particular public input is underprovided. ${ }^{10}$

By using a framework in which we observe firm valuations of public inputs directly, we circumvent the problems that arise in a standard production function approach where values of different public inputs are inferred from the estimated impacts on output. We show how the firm valuations can be readily aggregated and compared across countries and across inputs. The result is a set of equations, which we take to the data to answer questions about legacy effects by comparing formerly planned and market countries. Fig. 4 summarises the way we shall interpret the data. On the horizontal axis is GDP per capita. On the vertical axis is the reported cost of a public input (R), e.g. the court system, averaged across all firms in the country. We interpret this as the mean shadow price of the public input to the firms in the country. In the example in Fig. 4, we see that firms in formerly planned economies at both low and high country income levels report higher shadow prices (e.g. of using the court system) than do firms in market economies. We can also see that in this illustrative example the disadvantage of firms in formerly planned economies (denoted by Diff) through the bigger burden imposed by deficiencies in the court system is larger in low (L) income countries than in high $(\mathrm{H})$ income countries, shown in the diagram by Diff $\mathrm{L}>$ Diff $\mathrm{H}$.

In the next subsection, we set out the model behind Fig. 4. We then explain the data we use to construct the measures of R, the reported costs of public input constraints, and this is followed by a description of the econometric strategy that allows us to go from the individual firm survey responses to construct country-level estimates of reported costs and to test for differences between planned and market economies at different income levels. In Section 5, we report the results for the legacy hypotheses using these data and methods.

\subsection{Model}

As explained in more detail in the appendix (Appendix A.2) we use a model where public inputs are included in the private production function of a firm. Following Carlin et al. $(2006,2010)$ we interpret the answers to the subjective severity questions as reflecting the shadow price of public inputs. We use a simple single-period firm production function with two inputs, $N$ and $B$, which are combined to produce output $Y . N$ is employment; it is a variable input with no adjustment costs. $B$ is the flow of services from a public input. We normalize the price of output $Y$ to 1 . Firms differ in productivity, captured by a multiplicative productivity parameter $A$. We index countries by $j$ and firms by $i$. We assume the public input is supplied on identical terms to all firms in a country, so we write it as $\bar{B}_{j}$. Although the aggregate measures reported in Section 2 may capture some aspects of $\bar{B}_{j}$, the flow of public inputs to the firm is not observable. $\bar{B}_{j}$ captures the notion of a shared "business environment". The production function is:

$$
Y_{i j}=A_{i j} F\left(N_{i j}, \bar{B}_{j}\right) .
$$

Firms choose employment, $N$, to maximize profits $\pi$ for given technology $A$, public input $B$, and relative price of labour, $w_{j}$. As we show in the appendix, this leads to an estimating equation linking the reported shadow price of the public input and the level

\footnotetext{
${ }^{10}$ An important implication of the shadow price interpretation for firm-level studies is that it is inappropriate to include the scores as indicators of the flow of services on the right hand side when estimating a production function. See Carlin et al. $(2006,2010)$ for further discussion.
} 
of country GDP as follows:

$$
R_{i j}=\delta_{0}+\delta_{1} \bar{A}_{j}+\delta_{2} \operatorname{PLAN}_{j}+\delta_{3}\left(\operatorname{PLAN}_{j} * \bar{A}_{j}\right)+v_{i j}
$$

where $R_{i j}$ is the reported shadow price of the public input by firm $i$ in country $j$, and $\bar{A}_{j}$ is the mean country level of firm productivity, proxied here by country GDP per capita.

This allows us to answer the question whether there are differences in firm valuations of a given public input between formerly planned and market economies at comparable incomes, without needing to measure the supply of public inputs directly, i.e. the $\bar{B}_{j}$ s. Since we allow both position and the slope of the income-public input relationship to differ between planned and market economies as illustrated in Fig. 4, the answer to the question depends on the level of income where we are making the comparison. We choose the same two reference incomes as in Section 2 for our comparison, $\bar{A}_{L}=\log (\$ 3,500)$ and $\bar{A}_{H}=$ $\log (\$ 16,500)$, with $L$ indicating "low-income" and $H$ indicating "high-income".

The parameter values obtained by estimating Eq. (4) combined with these reference income levels generate the following predicted values for low-income $(\mathrm{L})$ and high-income $(\mathrm{H})$ planned $(\mathrm{P})$ and market $(\mathrm{M})$ economies:

$$
\begin{aligned}
& \hat{R}_{L M}=\hat{\delta}_{0}+\hat{\delta}_{1} \bar{A}_{L}, \\
& \hat{R}_{H M}=\hat{\delta}_{0}+\hat{\delta}_{1} \bar{A}_{H}, \\
& \hat{R}_{L P}=\left(\hat{\delta}_{0}+\hat{\delta}_{2}\right)+\left(\hat{\delta}_{1}+\hat{\delta}_{3}\right) \bar{A}_{L}, \\
& \hat{R}_{H P}=\left(\hat{\delta}_{0}+\hat{\delta}_{2}\right)+\left(\hat{\delta}_{1}+\hat{\delta}_{3}\right) \bar{A}_{H} .
\end{aligned}
$$

These four predicted values are statistics, and can be readily compared using standard least squares regression and hypothesis tests. We are interested in particular in the following comparisons, illustrated in Fig. 4, which capture how the impacts on firms of provision of the public input in question differ between planned and market economies at similar income levels, (Diff $L$ and Diff $H$ ). Note that Diff $>0$ indicates that the burden on firms is larger in formerly planned economies than in market economies, and that Diff $<0$ indicates that the burden in PEs is lower than in MEs, at the reference income level;

$$
\begin{aligned}
& \text { Diff } L \equiv \hat{R}_{L P}-\hat{R}_{L M}=\left(\hat{\delta}_{2}+\hat{\delta}_{3} \bar{A}_{L}\right) \\
& \text { Diff } H \equiv \hat{R}_{H P}-\hat{R}_{H M}=\left(\hat{\delta}_{2}+\hat{\delta}_{3} \bar{A}_{H}\right) .
\end{aligned}
$$

Finally, we can use the fitted values to test the differences in the rankings of the reported costs of different public inputs. How do the shadow prices of different public inputs compare in low-income planned and market economies and how do these rankings change with income? We construct four sets of rankings of public inputs from the four sets of fitted values $\hat{R}_{L P}, \hat{R}_{H P}, \hat{R}_{L M}$ and $\hat{R}_{H M}$. The statistical tests of the rankings are simple Wald tests of the differences between these fitted values. For example, if a public input such as the court system is ranked above another public input such as electricity for low-income ex-planned economies, we report whether the difference $\left(\hat{R}_{L P, \text { courts }}-\hat{R}_{L P, \text { electricity }}\right)$ is significant, and similarly for the other categories of countries.

\subsection{Data}

The surveys used here were conducted over a period of 9 years, from 2002 to 2010, and covered around 62,000 manufacturing firms in 202 separate surveys in 111 countries (see Appendix Table A2). Basic statistics on the surveys are presented in Table 4. Most of the surveyed firms are small or medium-sized enterprises (SMEs); mean log employment is about 35 persons. Most of the data on firms in formerly planned economies, and a small number of surveys of firms in market economies, were collected in the Business Environment and Enterprise Performance Surveys (BEEPS) conducted by EBRD; data on firms from the rest of the world, and a handful of additional surveys for transition countries, come from the World Bank's Enterprise Surveys (ES) programme. The original surveys collect data from both manufacturing and services firms. We limit our analysis to privately owned manufacturing firms to reduce the heterogeneity in the sample; the results of the analysis are in any case very similar when extended to include firms in services. Roughly $17 \%$ of the sample, or about 10,000 firms, were drawn from formerly planned economies. Slightly more than half of formerly planned economy firms in the sample were surveyed between 2002 and 2005 (BEEPS II and III, plus a handful of non-BEEPS surveys). Another survey of firms in formerly planned economies (BEEPS IV) was conducted in 2007-09. We present below two separate analyses. First, we test for legacy effects using the findings from the 2002-05 surveys in the former planned economies, which took place relatively early in the period of economic recovery. We then look at the results from the BEEPS IV surveys, which we refer to as "2008", that took place at the end of the recovery period and just prior to the global economic crisis. 
Table 4

Summary statistics, firm level survey data.

\begin{tabular}{|c|c|c|c|c|c|}
\hline & ALL & Market & Planned & Of which: 2002-05 (BEEPS II \& III) & Of which: 2008 (BEEPS IV) \\
\hline \multicolumn{6}{|l|}{ Country characteristics } \\
\hline Log GDP pc & 8.43 & 8.32 & 9.00 & 8.87 & 9.17 \\
\hline GDP pc $(\exp (\log ))$ & 4580 & 4085 & 8106 & 7130 & 9563 \\
\hline \multicolumn{6}{|l|}{ Sample sizes } \\
\hline No. firms & 62,032 & 51,677 & 10,355 & 5832 & 4523 \\
\hline No. countries & 111 & 83 & 28 & 28 & 27 \\
\hline No. surveys & 202 & 113 & 89 & 61 & 28 \\
\hline \multicolumn{6}{|l|}{ Firm characteristics } \\
\hline $\log N$ & 3.55 & 3.54 & 3.55 & 3.42 & 3.73 \\
\hline$N(\exp (\log ))$ & 34.7 & 34.6 & 34.9 & 30.4 & 41.6 \\
\hline foreign $(1 / 0)$ & 0.120 & 0.115 & 0.146 & 0.160 & 0.129 \\
\hline exporter $(1 / 0)$ & 0.291 & 0.281 & 0.342 & 0.335 & 0.350 \\
\hline importer $(1 / 0)$ & 0.249 & 0.232 & 0.331 & 0.330 & 0.334 \\
\hline small city $(1 / 0)$ & 0.675 & 0.672 & 0.691 & 0.661 & 0.729 \\
\hline \multicolumn{6}{|l|}{ Constraints (0-4) } \\
\hline Electricity & 1.48 & 1.56 & 1.11 & 0.65 & 1.70 \\
\hline Telecoms & 0.68 & 0.72 & 0.47 & 0.47 & 0.00 \\
\hline Transport & 0.94 & 0.96 & 0.83 & 0.59 & 1.14 \\
\hline Access Land & 0.85 & 0.84 & 0.88 & 0.67 & 1.14 \\
\hline Inad Educ Labor & 1.22 & 1.18 & 1.41 & 1.09 & 1.82 \\
\hline Macro Instability & 1.90 & 1.93 & 1.77 & 1.77 & 0.00 \\
\hline Gov Policy Unc & 1.62 & 1.59 & 1.78 & 1.78 & 0.00 \\
\hline Political Instability & 1.67 & 1.64 & 1.83 & 0.00 & 1.83 \\
\hline Tax Administration & 1.42 & 1.39 & 1.59 & 1.62 & 1.56 \\
\hline Labour Reg & 1.00 & 1.00 & 1.01 & 0.98 & 1.05 \\
\hline Customs & 0.99 & 0.96 & 1.11 & 1.19 & 1.00 \\
\hline Bus Licensing & 0.96 & 0.93 & 1.10 & 1.05 & 1.15 \\
\hline Courts & 0.95 & 0.87 & 1.25 & 1.19 & 1.33 \\
\hline Corruption & 1.57 & 1.59 & 1.49 & 1.29 & 1.72 \\
\hline Crime Theft Disorder & 1.15 & 1.16 & 1.09 & 0.94 & 1.28 \\
\hline
\end{tabular}

Notes: Means of GDP and $\mathrm{N}$ in levels are $\exp (\operatorname{mean}(\log (\mathrm{X}))$.

\subsection{Empirical strategy}

In the estimation of Eq. (4) we want to control for firm characteristics such as size and international engagement. Thus for each public input, $k$, we want to estimate

$$
R_{i j k}=\delta_{0 k}+\delta_{1 k} \bar{A}_{j}+\delta_{2 k} P L A N_{j}+\delta_{3 k}\left(P L A N_{j} * \bar{A}_{j}\right)+X_{i j} \Gamma_{k}+v_{i j k}
$$

where $X_{i j}$ is a vector of firm characteristics and a corresponding parameter vector $\Gamma_{k}$. The primary motivation for controlling for firm characteristics is that we do not want our comparisons across countries to be affected by differing sample compositions in the surveys used or by the compositions of the populations of firms. The characteristics $X_{i j}$ are defined so that $X_{i j}=0$ defines a "benchmark firm"; for example, our benchmark firm is domestically-owned, and hence $X_{i j}$ includes a dummy variable $F O_{i j}$ which equals 1 when the firm is foreign-owned and equals 0 when it is domestically-owned. Because the benchmark firm is defined at $X_{i j}=0$, the predicted reported costs $\hat{R}$ in Eqs. (5) through (8) are unchanged. The effect is to define conditional means that can be interpreted as the country means for a benchmark firm with a defined set of characteristics that is the same for every country. These conditional means are the focus of our tests of legacy effects.

We use the following two-step estimation procedure. In the first step, we obtain estimates of the parameter vector $\Gamma_{k}$ using survey fixed effects. We estimate separately for planned and market economies so that the parameter vector $\Gamma_{k}$ can vary for the two groups of countries. The residuals and fixed effects are then used to construct estimates of the reported costs $\tilde{R}_{i j k}$ with the firm characteristics $X_{i j}$ partialled out. In the second step, estimates of $\hat{R}_{L P, k}, \hat{R}_{H P, k}, \hat{R}_{L M, k}$ and $\hat{R}_{H M, k}$ are obtained for each public input $k$ by regressing the partialled-out reported costs $\tilde{R}_{i j k}$ on log GDP per capita interacted with the PLAN dummy as regressors and then calculating the desired fitted values. ${ }^{11}$

The benchmark firm is privately owned and in manufacturing, by virtue of the construction of the datasets used. It has 30 employees, less than $10 \%$ foreign ownership, is exporting less than $10 \%$ of its sales, and is not a direct importer of inputs. The first step thus estimates the following fixed-effects regression separately for planned and market economies:

$$
R_{i j k}=\gamma_{1 k} N 30_{i j}+\gamma_{2 k} F O_{i j}+\gamma_{3 k} E X_{i j}+\gamma_{4 k} I M_{i j}+f_{j k}+\varepsilon_{i j k}
$$

\footnotetext{
11 The advantage of this two-step procedure, besides computational simplicity, is robustness. Direct estimation of Eq. (11) would require the assumption that the firm characteristics $X_{i j}$ are orthogonal to the full composite error term $v_{i j k}$, including the country-specific error $u_{j}$. The fixed-effects first step in the procedure we actually use assumes only that the firm characteristics are orthogonal to the idiosyncratic error $\varepsilon_{i j k}$ (see Appendix Table A3).
} 
where the variable $N 30$ is $\log (N / 30),{ }^{12} f_{j k}$ is the survey-specific fixed effect and the remaining variables are dummies corresponding to the characteristics listed above. The benchmark reported cost of input $k$ for firm $i$ in country survey $j$ from this first-step estimation is simply:

$$
\tilde{R}_{i j k}=\hat{f}_{j k}+\hat{\varepsilon}_{i j k} .
$$

$\tilde{R}_{i j k}$ is then used as the dependent variable in estimation by OLS of

$$
\tilde{R}_{i j k}=\delta_{0 k}+\delta_{1 k} \bar{A}_{j}+\delta_{2 k} \operatorname{PLAN}_{j}+\delta_{3 k}\left(\operatorname{PLAN}_{j} * \bar{A}_{j}\right)+\zeta_{i j k} .
$$

The estimated parameters from (13) and the reference income levels and country group definitions give us our statistics as defined in Eqs. (5) through (10).

The statistical tests of how the reported costs for a single public input $k$ differ across reference income levels and country groups are conducted using Wald tests and the estimated parameters of Eq. (13); the covariance estimator used is robust to heteroskedasticity. To test for whether, for a given country group and income level, the reported costs $\hat{R}$ of two constraints $k$ and $q$ differ, we use the corresponding two estimations of Eq. (13) and perform a Wald test with a cluster- and heteroskedasticity-robust covariance estimator that accounts for the possible within-firm correlation of the two error terms $\zeta_{i j k}$ and $\zeta_{i j q}{ }^{13}$

\section{How salient were the legacies of communism for growth in the market economy?}

In this section, we use the reported costs of the public input constraints as estimated using the methods set out in Section 4 to answer the question of the continuing salience of the legacies of communism for the mainly small and medium-sized firms covered in the business environment surveys. The aim is to test the hypothesis that differences in the burdens imposed on the growth of firms by unreliable public inputs in planned and market economies can be linked to legacies of planning. The firm-level data allow us to look separately at three elements of physical infrastructure (electricity, transport and telecommunications), access to skilled labour, and a number of institutional inputs. This means we can see whether there is evidence of the impact on firms of the greater endowments of physical infrastructure and education with which countries ended planning (relative to their GDP per capita comparators) and the gaps in market institutions with which they entered transition to the market economy. We undertake these comparisons both in 2002-05, after a decade of transition, and in 2008, on the eve of the global financial crisis. ${ }^{14}$ Though there are some small differences in the design of the earlier and later surveys, the latter offers us the opportunity to observe whether the legacy effects of planning persisted through the period of strong growth. ${ }^{15}$

Table 5 summarises the predicted costs for the benchmark firm of different elements of the external environment at two different levels of GDP per capita (low-income $=\$ 3500$ and high-income $=\$ 16,500)$ in formerly planned and market economies. Entries in bold italics signify a rating above the full sample mean of 1.1, while the other shaded cells in normal font signify those below. ${ }^{16}$

When we compare low-income formerly planned and market economies in 2002-05, legacy effects of planning are clear (first column headed Diff L): in terms of their external environment, firms in low-income planned economies were poor in different ways from firms in market economies. Firms in poor planned economies benefited from more satisfactory provision of physical infrastructure, access to skilled labour, access to land, were less burdened by labour regulation and reported lower costs from crime and theft than did firms in poor market economies. They reported more serious problems than poor market economies in relation to a number of aspects of the institutional environment: tax administration, customs, business licensing and courts.

When comparing high-income planned and market economies in 2002-05, the differences were fewer (first column headed Diff H). Electricity continued to pose fewer problems than was the case for firms in market economies but there was no difference with their market economy comparators in relation to educated labour and the other aspects of physical infrastructure. This is consistent with the hypothesis that countries that had undergone industrialisation as market economies had institutional legacies stretching back beyond the planning era. The institution that stands out in this regard is labour regulation. Firms in richer planned economies rated problems with labour regulation in a similar way to firms in richer market economies, namely as more serious than the average. This marks out high-income planned and market economies from both sets of low-income countries. These results underline the initial hypothesis that the two groups of planned economies are different. Planning accelerated the industrialisation of low-income countries, leaving them

\footnotetext{
${ }^{12} \log (N / 30)=\log (N)-\log (30)$, i.e., our size measure is constructed so that it takes the value zero for a firm with 30 employees.

13 The Stata command used to pool the estimates of Eq. (13) for each input $k$ is suest with clustering by firm. The results are equivalent to stacking the dataset by public input, interacting the regressors in Eq. (13) with dummies for each input, estimating by OLS (so that the estimated coefficients are identical to those obtained when estimating equation-by-equation) and using the cluster-robust covariance estimator for testing.

${ }^{14}$ We use other questions in the survey to check whether the results of the 2007-09 round were contaminated by the early effects of the financial crisis. Although in our analysis in this paper we do not use the questions on access to or cost of finance, we can use the answers to those questions to check for evidence of the credit crunch. While the average complaint level across all dimensions of the business environment rises in 2008 compared to $2002-05$, the 2008 complaint level for problems related to finance remains similar to 2002-05. This evidence from the finance question suggests that the responses from 2008 should be interpreted as "the eve of the financial crisis" rather than "early in the financial crisis".

15 The main change was that the questions on government policy uncertainty and macroeconomic stability were dropped. A related question was asked instead on political instability. The question about telecoms was also dropped for manufacturing firms. In short, the top- and bottom-ranked constraints were dropped.

16 In Table 5, we use a fairly high threshold for "significance", i.e., we require the absolute value to be different from 0.1 . This is a way of capturing both "statistical significance" and "economic significance". In Appendix Table A4, where the second stage results are reported, standard errors are shown in the usual way with bold italics used to indicate the coefficients that are significantly different from zero.
} 
Formerly planned economies (PE 2002-05; 2008) and market economies (ME).

\begin{tabular}{|c|c|c|c|c|c|c|c|c|c|c|}
\hline & \multicolumn{6}{|c|}{ Levels ( $>$ or < 1.1) } & \multicolumn{4}{|c|}{ Differences $(>0.1$ or $<-0.1)$} \\
\hline & \multicolumn{2}{|c|}{ PE 2002-05 } & \multicolumn{2}{|c|}{ PE 2008} & \multicolumn{2}{|l|}{$\mathrm{ME}$} & \multicolumn{2}{|c|}{ PE 2002-05 vs. ME } & \multicolumn{2}{|c|}{ PE 2008 vs. ME } \\
\hline & LP & $\mathrm{HP}$ & LP & HP & LM & HM & Diff L & Diff $\mathrm{H}$ & Diff L & DIff $\mathrm{H}$ \\
\hline Electricity & $0.77^{*}$ & $0.55^{*}$ & $1.98^{*}$ & $1.55^{*}$ & $1.57^{*}$ & $0.71^{*}$ & $-0.80^{*}$ & $-0.16^{*}$ & $0.41^{*}$ & $0.85^{*}$ \\
\hline Telecoms & $0.49^{*}$ & $0.44^{*}$ & n.a. & n.a. & $0.67^{*}$ & $0.42^{*}$ & $-0.18^{*}$ & 0.02 & n.a. & n.a. \\
\hline Transport & $0.57^{*}$ & $0.58^{*}$ & 1.16 & 1.08 & $0.92^{*}$ & $0.54^{*}$ & $-0.35^{*}$ & 0.04 & $0.24^{*}$ & $0.54^{*}$ \\
\hline AccessLand & $0.70^{*}$ & $0.63^{*}$ & $1.25^{*}$ & 1.09 & $0.88^{*}$ & $0.41^{*}$ & $-0.18^{*}$ & $0.22^{*}$ & $0.37^{*}$ & $0.68^{*}$ \\
\hline InadEducLabor & $0.89^{*}$ & $1.15^{*}$ & $1.81^{*}$ & $1.67^{*}$ & 1.10 & 1.12 & $-0.21^{*}$ & 0.03 & $0.71^{*}$ & $0.55^{*}$ \\
\hline MacroInstability & $1.76^{*}$ & $1.70^{*}$ & n.a. & n.a. & $1.86^{*}$ & $2.05^{*}$ & -0.09 & $-0.36^{*}$ & n.a. & n.a. \\
\hline GovPolicyUnc & $1.76^{*}$ & $1.80^{*}$ & n.a. & n.a. & $1.57^{*}$ & $1.45^{*}$ & $0.18^{*}$ & $0.34^{*}$ & n.a. & n.a. \\
\hline PoliticalInstability & n.a. & n.a. & $2.04^{*}$ & $1.72^{*}$ & $1.60^{*}$ & $1.85^{*}$ & n.a. & n.a. & $0.44^{*}$ & -0.13 \\
\hline TaxAdministration & $1.64^{*}$ & $1.51^{*}$ & $1.44^{*}$ & $1.53^{*}$ & $1.34^{*}$ & $1.04^{*}$ & $0.30^{*}$ & $0.46^{*}$ & 0.10 & $0.49^{*}$ \\
\hline LaborReg & $0.74^{*}$ & $1.16^{*}$ & $0.75^{*}$ & 1.09 & $0.90^{*}$ & $1.07^{*}$ & $-0.16^{*}$ & 0.09 & -0.15 & 0.02 \\
\hline Customs & 1.08 & $0.80^{*}$ & 1.03 & $0.64^{*}$ & $0.74^{*}$ & $0.45^{*}$ & $0.35^{*}$ & $0.35^{*}$ & $0.30^{*}$ & $0.19^{*}$ \\
\hline BusLicensing & 1.08 & $0.93^{*}$ & 1.14 & 1.11 & $0.88^{*}$ & $0.80^{*}$ & $0.20^{*}$ & 0.14 & $0.26^{*}$ & $0.31^{*}$ \\
\hline Courts & $1.14^{*}$ & $1.24^{*}$ & $1.34^{*}$ & $1.27^{*}$ & $0.80^{*}$ & $0.77^{*}$ & $0.35^{*}$ & $0.47^{*}$ & $0.54^{*}$ & $0.50^{*}$ \\
\hline Corruption & $1.39^{*}$ & $1.17^{*}$ & $1.94^{*}$ & $1.59^{*}$ & $1.52^{*}$ & $1.21^{*}$ & -0.14 & -0.04 & $0.42^{*}$ & $0.38^{*}$ \\
\hline CrimeTheftDisorder & $0.95^{*}$ & $0.96^{*}$ & $1.65^{*}$ & $1.16^{*}$ & $1.14^{*}$ & $0.97^{*}$ & $-0.19^{*}$ & -0.02 & $0.51^{*}$ & $0.18^{*}$ \\
\hline
\end{tabular}

Notes: This table reports tests of constraints across country groups: in the "Levels" columns, the tests are for each group on its own vs. the overall mean constraint level of 1.1. In the "Differences columns", the tests are vs. 0.1 if differences are positive and vs. -0.1 if they are negative.

Diff $\mathrm{L}=\mathrm{LP}$ vs LM (low-income planned economies vs low-income market economies).

Diff $\mathrm{H}=\mathrm{HP}$ vs HM (high-income planned economies vs high-income market economies).

with features quite distinct from their market economy peers. ${ }^{17}$ However, it is clear that, as in poor planned economies, in rich ones, firms were more troubled by burdens imposed by courts, tax administration and customs than was the case in market economies.

The results for 2008 suggest that the pressure of rapid growth was reflected in the evaluation of the external constraints firms faced by firms in the formerly planned economies. As compared with the market economy sample (which pools all of the surveys administered between 2002 and 2010) firms in planned economies in 2008 reported higher costs of constraints virtually across the board (see the second Diff L and Diff H columns of Table 5). In both groups, the extent to which electricity was viewed as a problem increased markedly in the 2008 survey. ${ }^{18}$

We can use the methodology developed in Section 4 to compare how public input constraints are ranked in the different country groups. The purpose of comparing rankings rather than absolute ratings of the severity of constraints is to adjust for country differences in the average reported severity: we look at whether particular constraints rank relatively high or relatively low for firms in the countries concerned. The results are presented in Tables A5 and A6 in the appendix, for 2002-05 and 2008 respectively. There are some common patterns in the ranking of constraints across all country groups. For example, in the light of the debate about the Washington and post-Washington consensus, it is striking that macroeconomic stability and government policy uncertainty show up as the elements of the external environment of most concern to firms in all country groups in 2002-05. Telecoms is bottom-ranked in each country group, which may be a reflection of the extent to which telephony is now considered by firms to be a private rather than a public good.

The ranking exercise shows that in both groups of ex-planned economies, the three elements of physical infrastructure are at the bottom. As might be expected in the light of the emphasis on education under planning, for the poor planned economies, access to skilled labour is also low-ranked and not viewed as a major obstacle to growth. For both groups, the courts are ranked high among institutional constraints.

Consistent with the results reported above, it is across the two groups of low-income countries where stark differences in the ranking of constraints appear. Electricity is a serious problem for firms in market economies; the courts are not. The reverse is the case for planned economies. Firms in higher-income planned economies ranked constraints in a more similar way to their market-economy comparators than was the case in low-income planned economies. The main differences were that the courts were ranked toward the top and access to skilled labour well down the list in planned economies whereas the reverse was the case in market economies. The difficulties reported in relation to the courts in the richer planned economies suggest that although

\footnotetext{
17 Appendix Table A4 confirms the difference between the two groups of planned economies and their market economy peers highlighted in the Diff L and Diff $\mathrm{H}$ columns of Table 5. If differences between planned and market economies were shared equally across the income distribution, the slopes of the P and $\mathrm{M}$ lines would be equal and the slope dummy would be insignificant. As Table A4 shows, it is almost always significant.

${ }^{18}$ Although there may be concern that the higher reported constraints in relation to electricity reflect the oil price spike in 2007 rather than the reliability of the infrastructure, other evidence does not support this. For example, the correlation between power outages and electricity as a constraint is stronger in 2008 than in previous years in the planned economies. Moreover, unlike in the planned economies, there is no increase in electricity complaints in 2008 in Turkey, which was also surveyed in that year as part of the BEEPS IV survey, supporting the conclusion that this is a phenomenon specific to the formerly planned economies now in transition, and not a reflection of changes in world energy prices. Additional support for the hypothesis that capacity and or access constraints rather than price effects dominate comes from the fact that it is firms that expanded employment by more than $10 \%$ over the previous three years that complain more about electricity.
} 
some institutions could be re-established relatively quickly, problems with the judicial system persisted. Overall, this suggests a conclusion reminiscent of Tolstoy: rich countries resemble one another whether they underwent planning and transition or not; poor countries are unhappy in their own different ways.

By the time of the 2008 survey, as reported in Tables A6a and A6b, priorities for firms had changed a great deal and the value of inherited legacies appears to have eroded. In both poor and rich formerly planned economies, electricity moved from close to the bottom to the top-ranked set of constraints. Problems with availability of skilled labour also emerged as serious in both groups of countries, where it moved from well down the ranking to the top-ranked set in the high-income planned economies and the second-ranked set in the low-income ones.

Plausible reasons for the emergence of electricity and skills as serious obstacles for firms in transition are on the one hand the depreciation of the initial high endowments and inadequate investment during the phase of transition, and on the other, a greater mismatch between endowments and the needs of firms in the market economy in a phase of rapid growth. Our data do not allow us to distinguish cleanly between the contributions of each of these. Since the formerly planned economies retained their advantage over comparable market economies in the aggregate indicators of physical infrastructure capacity and education between the beginning of transition and 2008 (Table 3), our results suggest that although the communist legacy brought with it comparatively high quantities of these public inputs (measured at national level), qualitative aspects such as geographical distribution and orientation toward the needs of highly vertically integrated production and distribution systems were increasingly revealed as ill-suited to the market economy environment. An example that reflects the rigidity of the planning system was the orientation of the railway network to service the needs of heavy industrial users and the haulage of raw materials. More generally, higher reported costs are likely to relate to issues such as the flexibility of access to the grid; tariff structures; balance of transport modes and tariffs; and the value of the existing mix of qualifications and skills. There are numerous descriptions in the literature of the mismatch between inherited infrastructure and best practice arrangements in a market economy (e.g., EBRD, 1996, Carbajo and Fries, 1997, Aghion and Schankerman, 1999, von Hirschhausen, 2002, Feinberg and Meurs, 2008). The firm-level data suggest that the predicted mismatches did not emerge as constraints on firms until the end of the second decade of transition.

\section{Conclusion}

We suggested at the outset that an evaluation of the legacy of central planning was likely to involve a trade-off between the adverse effects of static allocative inefficiency and poor incentives for innovation, and the beneficial effects of provision of greater quantities of physical infrastructure and human capital than was typical of market economies. We have shown that the overall terms of this trade-off depended to a striking extent on countries' initial levels of development. Planning appears not to have hampered the development of initially poor countries. Indeed, there is evidence that for initially poor countries, the long-run benefits of physical infrastructure and human capital substantially outweighed the long-run economic costs of static inefficiencies and weak innovation incentives. Furthermore, countries that were still poor at the end of the central planning era were quite different from other poor countries, and appeared to benefit in the market economy from the legacy effects of their infrastructure and human capital endowments. However, their ability to take advantage of the opportunities of the market economy was limited by obstacles such as poor courts and tax administration, which had not been a handicap under central planning but were so to a high degree afterwards.

The more prosperous adopters of planning ended up certainly no better off and (under most though not all comparisons) substantially worse off than their pre-planning peers. Countries that were already comparatively prosperous before the imposition of central planning appear to have benefited less from the infrastructure and human capital advantages of planning, and suffered more from the costs of losing market incentives.

To uncover evidence on the hypothesized channels from the initial level of development to how countries fared under planning, we turned to the transition years and legacy effects. We analysed firm-level data reporting how various aspects of their business environment affected the opportunity for firms to grow. In 2002-05, after more than a decade of transition, firms in rich formerly planned economies were found to benefit less from infrastructure and education advantages over their market economy peers than do those in poor planned economies, and to be hampered by weaknesses in market institutions different from those that are most problematic in market economies. Overall, though, rich formerly planned economies differ less from their market economy counterparts than do poor planned economies, which continue to have strengths and to face handicaps that are quite unlike those of poor countries that never went through the central planning process.

Finally, we tested whether the legacy effects of Soviet planning, which persist in the aggregate data on infrastructure and education in 2008, continue to reflect the evaluation by firms of their external environment in the years of strong growth running up to the global financial crisis. We found that they do not. In the 2008 survey, firms in formerly planned economies report higher costs of their external business environment than do market economy firms. Most striking is the disappearance of the advantage of low-income planned economies in electricity and education. In poor and rich formerly planned economies, electricity and education are rated as more costly to the firm than is the case for market economies, and both are highly ranked as compared with other aspects of the external environment. Taken together with the results of the 2002-2005 surveys, this suggests that the initial advantages of planned economies in terms of the quantity of prior investments in infrastructure and human capital masked quality handicaps which caught up with these countries as growth went ahead. A year of education and a kilometre of railway track in a planned economy were simply less productive than a year of education and a kilometre of track in a market economy, and the fact that formerly planned economies began transition with higher quantities of both was not enough to protect them from the consequences of these quality handicaps. 


\section{Appendix A}

\section{A.1. Country data notes for Section 2 and Tables $1 a, 1 b$ and 2}

GDP per capita in 1988 and 2005 is at PPP in 2005 \$US from World Bank WDI, except as noted.

GDP per capita in 1913 and 1937 is from Maddison in 1990 \$US, converted to 2005 \$US using US GDP in 1990 from Maddison (in \$1990) and World Bank WDI (in \$2005), except as noted.

Broadberry and Klein (2008) is used for GDP per capita in 1913 in Russia and 1937 in Romania, the latter in preference to Maddison because of the postwar territorial change associated with the separation of Moldova from Romania (Broadberry-Klein refer to the prewar territory of Romania).

1913 proxies and estimates:

Ukraine, Belarus: proxy is Russia.

Armenia, Azerbaijan, Georgia: proxy is Turkey.

Kazakhstan, Kyrgyzstan, Tajikistan, Turkmenistan: proxy is India.

Uzbekistan: proxy is Iran/Iraq.

Bangladesh, Pakistan: proxy is India.

Uzbekistan was more urbanized than the rest of Central Asia in 1926. Hence we proxy Uzbek GDP using Iran rather than India.

Source: Henze (1949).

1937 proxies and estimates:

Estonia, Latvia: proxy is Finland.

Lithuania: proxy is Poland.

Moldova and Romania: the Broadberry and Klein (2008) estimate for Romania in 1937 is used for both Romania and Moldova.

Czech Republic, Slovakia: Czechoslovakia and Capek and Sazama (1993); see below.

Yugoslav republics: Yugoslavia 1937 and 1953 republic data; see below.

Ecuador and Paraguay is 1939 GDP per capita.

Jamaica is 1938 GDP per capita.

Myanmar is average of 1936 and 1938 GDP per capita.

"The prewar development levels of Estonia and Finland were nearly equal, and by 1939, the Estonian standard of living was approximately on par with - if not slightly higher than - that of Finland, and Latvia was not far behind." Source: Hedegaard and Lindström (1998: 15).

Yugoslav republic GDP per capita 1937 is based on Yugoslavia 1937 from Maddison and 1953 relative social product per head in the separate republics in current prices. Source: Gregory (1973).

Czech and Slovak GDP per capita 1937 is based on Czechoslovakia 1937 from Maddison and 1937 relative shares of income and population from Capek and Sazama (1993).

1988 and 2008 estimates:

The main source is the World Bank WDI PPP data in 2005 \$US. In several cases, 1988 and 2008 figures use as a supplementary source the Conference Board "Total Economy Database" (TED). TED provides two PPP series, one in 2010 "EKS" \$US and one in 1990 "GK" \$US. The latter is compatible with Maddison's PPP series. TED data below refer to the EKS series except where noted.

Armenia, Belarus, Kazakhstan, Lithuania, Czech Republic, Slovenia, Croatia, Macedonia: WB figure for 1990 backwards chain-linked from TED to obtain 1989; 1988 is set $=1989$.

Azerbaijan: 1988 based on 1989 WB figure backwards chain-linked from TED.

Russia: $1988=1989$.

Taiwan, Iraq, Serbia \& Montenegro, Bosnia \& Herzegovina: TED data converted to 2005 dollars using US 2005 GDP per capita from WB in 2005 \$US and TED in 2010 \$US.

Serbia \& Montenegro: $1988=1989$.

Bosnia: 1988 and $1989=1990$.

Poland: WB figure for 1990 backwards chain-linked from TED to obtain 1988.

Myanmar: from TED GK series in 1990 \$US converted to 2005 \$US using US 1990 GDP per capita from WB in 2005 \$US and TED GK data in 1990 \$US.

\section{A.2. Deriving the estimating equation for Section 4:}

Denoting a maximum-value function by a superscript *, we have (from Eq. (3)):

$$
\begin{aligned}
& N_{i j}^{*}=N^{*}\left(A_{i j}, \bar{B}_{j}, w_{j}\right) \\
& \pi_{i j}^{*}=\pi^{*}\left(A_{i j}, \bar{B}_{j}, w_{j}\right)=A_{i j} F\left(N_{i j}^{*}, \bar{B}_{j}\right)-w_{j} N_{i j}^{*} .
\end{aligned}
$$

Our aim is to compare the impact of a public input on firm performance in different countries or types of countries without the need to measure $\bar{B}_{j}$. We refer to the firms' responses to the business environment questions (the ranking from "no obstacle" to "very severe obstacle") as the firm's "reported cost" $R_{i j}$ of a public input. We interpret it as the gap between the firm's profit in the 
hypothetical situation where the public input provided is of sufficient quality that it poses a negligible obstacle to the firm's operations and growth, and the firm's profit in reality, given the actual quality of public input provided.

If we denote the level of public input provided in an ideal, high-quality business environment as $\overline{\bar{B}}_{j}$, we have

$$
R_{i j}=\pi^{*}\left(A_{i j}, \overline{\bar{B}}_{j}, w_{j}\right)-\pi^{*}\left(A_{i j}, \bar{B}_{j}, w_{j}\right) .
$$

The marginal analogue of the reported cost $R_{i j}$ for small changes in the public input is therefore simply the derivative of the profit function:

$$
R_{i j} \approx \frac{\partial \pi_{i j}^{*}}{\partial \bar{B}_{j}} \equiv \lambda_{i j} .
$$

By the envelope theorem for constrained maximization, the derivative of the profit function $\pi_{i j}^{*}$ with respect to a constrained or fixed input is simply the shadow price of the input $\lambda_{i j}$. For this reason, Carlin et al. (2006) suggest we can interpret the responses to "Subjective Severity" questions as the shadow prices of shortcomings in the public input $\bar{B}_{j}$. Two straightforward results are that the shadow price of $\bar{B}_{j}$ is decreasing in $\bar{B}_{j}$ :

$$
\frac{\partial \lambda_{i j}}{\partial \bar{B}_{j}} \equiv \frac{\partial^{2} \pi_{i j}^{*}}{\partial \bar{B}_{j}^{2}}<0
$$

and is increasing in the productivity of the firm:

$$
\frac{\partial \lambda_{i j}}{\partial A_{i j}} \equiv \frac{\partial^{2} \pi_{i j}^{*}}{\partial \bar{B}_{j} \partial A_{i j}}>0
$$

i.e., a higher productivity firm will report higher costs of a poor public input than a lower productivity firm - even though they share the same business environment.

The first step in taking the model to the data is simply to linearise and add an error term $\eta_{i j}$ :

$$
R_{i j}=\alpha_{0}+\alpha_{1} A_{i j}+\alpha_{2} \bar{B}_{j}+\eta_{i j},
$$

where we expect that $\alpha_{1}>0$ and $\alpha_{2}<0$. Since our focus in this paper is variation across countries rather than across firms within countries, ${ }^{19}$ we say that firm productivity is randomly distributed around a country-specific mean:

$$
A_{i j}=\bar{A}_{j}+e_{i j} .
$$

Mean productivity $\bar{A}_{j}$ is also a proxy for a country's level of development or income per capita, and we expect provision of public inputs to vary systematically with income as we saw using aggregate proxy indicators for public inputs presented in Figs. 2 and 3. We use a simple linear formulation for the country provision of public input $\bar{B}_{j}$ :

$$
\bar{B}_{j}=\beta_{0}+\beta_{1} \bar{A}_{j}+u_{j}
$$

where $u_{j}$ is a country-level error term.

Substituting Eqs. (A9) and (A10) into (A8), the equation for reported cost $R_{i j}$, we obtain

$$
R_{i j}=\delta_{0}+\delta_{1} \bar{A}_{j}+v_{i j}
$$

where

$$
\begin{aligned}
& \delta_{0} \equiv \alpha_{0}+\alpha_{2} \beta_{0} \\
& \delta_{1} \equiv \alpha_{1}+\alpha_{2} \beta_{1}
\end{aligned}
$$

and $v_{i j}$ is a composite error term:

$$
v_{i j} \equiv \eta_{i j}+\alpha_{1} e_{i j}+\alpha_{2} u_{j} .
$$

The slope of the relationship in (A11) will be positive or negative depending on the values of the parameters $\alpha_{1}, \alpha_{2}$ and $\beta_{1}$. For example, if public input provision increases quickly enough with income (large $\beta_{1}$ ) and/or the shadow price of the input falls quickly as provision improves (large $\alpha_{2}$ ), both relative to how quickly the shadow price of the input increases with firm productivity $\left(\alpha_{1}\right)$, the income-reported cost relationship will be downward sloping.

Eq. (A11) can be implemented empirically by using GDP per capita for $\bar{A}_{j}$. The dependent variable is the $R_{i j}$ for a particular public input reported by firm $i$ in country $j$. The resulting parameter estimates can be used together with a chosen reference level of income for $\bar{A}_{\text {ref }}$ to obtain a predicted value $\hat{R}_{\text {ref }}$. The interpretation of $\hat{R}_{\text {ref }}$ is that it is the reported cost or shadow price we would predict for a typical firm in a country with income $\bar{A}_{r e f}$. This predicted value is a statistic, and hence we can use it in hypothesis testing or to construct confidence intervals.

\footnotetext{
19 See Carlin et al. $(2006,2010)$ for applications of this framework that explore the relationship between $R_{i j}$ and firm productivity.
} 
Table A1

Components of aggregate business environment indicators.

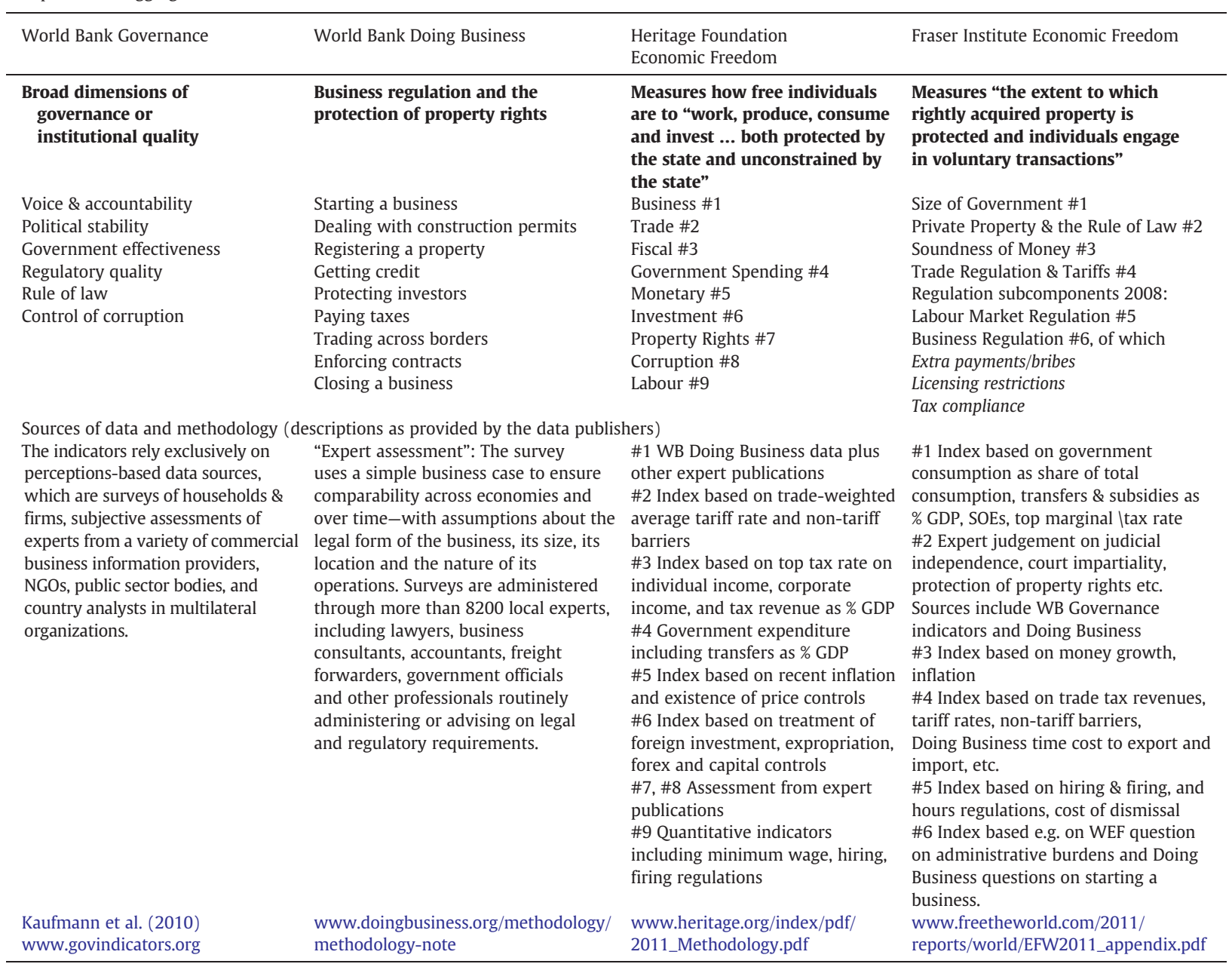

This approach allows us to compare the impact of a public input on firm performance in different countries or types of countries without the need to measure $\bar{B}_{j}$. We augment the public input provision Eq. (A10) with planned-economy slope and intercept dummies, estimating separately for each public input $k$ :

$$
\bar{B}_{j}=\beta_{0 k}+\beta_{1 k} \bar{A}_{j}+\beta_{2 k} P L A N_{j}+\beta_{3 k}\left(\operatorname{PLAN}_{j} * \bar{A}_{j}\right)+u_{j k}
$$

and then to obtain a feasible estimating equation in observables, we substitute Eqs. (A9) and (A15) into Eq. (A8) and get our basic reported cost estimating equation:

$$
R_{i j k}=\delta_{0 k}+\delta_{1 k} \bar{A}_{j}+\delta_{2 k} P L A N_{j}+\delta_{3 k}\left(P_{L A N} * \bar{A}_{j}\right)+v_{i j k}
$$

where $\delta_{0 k}, \delta_{1 k}$ and $v_{i j k}$ are defined as earlier, and

$$
\begin{aligned}
& \delta_{2 k} \equiv \alpha_{2 k} \beta_{2 k} \\
& \delta_{3 k} \equiv \alpha_{2 k} \beta_{3 k} .
\end{aligned}
$$

It is important to note that the parameters $\beta_{0}$ and $\beta_{1}$ relating country income to public infrastructure provision in Eqs. (A10) and (A15) need not have a structural interpretation. ${ }^{20}$ Rather, country income is being used here as a control, and the predicted reported costs $\hat{R}$ obtained from the estimation of Eq. (A16) should be interpreted simply as estimates conditional on country income. Instead of working with parameters $\beta_{2 k}$ and $\beta_{3 k}$, we work with the parameters scaled by $\alpha_{2 k}$.

\footnotetext{
${ }^{20}$ For example, we expect income to affect infrastructure provision - richer countries can afford more - but we also expect infrastructure provision to affect income - more infrastructure raises country income.
} 
Table A2

Enterprise survey data - country coverage by year.

The table below lists the number of firms in the sample by group (planned economy or market economy), country and year. All data was obtained from the World Bank's Enterprise Surveys website, http://www.enterprisesurveys.org.

\begin{tabular}{|c|c|c|c|c|c|c|c|c|c|c|}
\hline Country & 2002 & 2003 & 2004 & 2005 & 2006 & 2007 & 2008 & 2009 & 2010 & Total \\
\hline \multicolumn{11}{|l|}{ Planned economies } \\
\hline Albania & 60 & & & 71 & & 110 & & & & 241 \\
\hline Armenia & 54 & & & 217 & & & & 112 & & 383 \\
\hline Azerbaijan & 35 & & & 185 & & & & 111 & & 331 \\
\hline Belarus & 32 & & & 52 & & & 74 & & & 158 \\
\hline Bosnia and Herzegovina & 56 & & & 64 & & & & 118 & & 238 \\
\hline Bulgaria & 44 & & 324 & 53 & & 538 & & 95 & & 1054 \\
\hline Croatia & 29 & & & 62 & & 338 & & & & 429 \\
\hline Czech Republic & 63 & & & 78 & & & & 84 & & 225 \\
\hline Estonia & 29 & & & 39 & & & & 90 & & 158 \\
\hline Georgia & 30 & & & 47 & & & 117 & & & 194 \\
\hline Hungary & 51 & & & 352 & & & & 103 & & 506 \\
\hline Kazakhstan & 41 & & & 334 & & & & 179 & & 554 \\
\hline Kyrgyz Republic & 42 & 102 & & 53 & & & & 91 & & 288 \\
\hline Latvia & 28 & & & 33 & & & & 89 & & 150 \\
\hline Lithuania & 35 & & 157 & 41 & & & & 97 & & 330 \\
\hline Macedonia, FYR & 41 & & & 55 & & & & 114 & & 210 \\
\hline Moldova & 42 & 103 & & 198 & & & & 107 & & 450 \\
\hline Montenegro & & 42 & & & & & & 37 & & 79 \\
\hline Poland & 97 & 105 & & 514 & & & & 149 & & 865 \\
\hline Romania & 70 & & & 373 & & & & 184 & & 627 \\
\hline Russian Federation & 111 & & & 137 & & & & 585 & & 833 \\
\hline Serbia & & 101 & & & & & & 129 & & 230 \\
\hline Serbia and Montenegro & 58 & & & 63 & & & & & & 121 \\
\hline Slovak Republic & 25 & & & 32 & & & & 81 & & 138 \\
\hline Slovenia & 45 & & & 55 & & & & 101 & & 201 \\
\hline Tajikistan & 34 & 96 & & 50 & & & 113 & & & 293 \\
\hline Ukraine & 121 & & & 164 & & & 463 & & & 748 \\
\hline Uzbekistan & 44 & 100 & & 63 & & & 114 & & & 321 \\
\hline Total PEs & 1317 & 649 & 481 & 3385 & & 986 & 881 & 2656 & & 10,355 \\
\hline \multicolumn{11}{|l|}{ Market economies } \\
\hline Afghanistan & & & & & & & 121 & & & 121 \\
\hline Algeria & 367 & & & & & & & & & 367 \\
\hline Angola & & & & & 214 & & & & & 214 \\
\hline Argentina & & & & & 1387 & & & & & 1387 \\
\hline Bangladesh & 970 & & & & & 1196 & & & & 2166 \\
\hline Benin & & & 144 & & & & & & & 144 \\
\hline Bolivia & & & & & 770 & & & & & 770 \\
\hline Botswana & & & & & 113 & & & & & 113 \\
\hline Brazil & & 1619 & & & & & & 902 & & 2521 \\
\hline Burkina Faso & & & & & 51 & & & 93 & & 144 \\
\hline Burundi & & & & & 101 & & & & & 101 \\
\hline Cambodia & & 62 & & & & & & & & 62 \\
\hline Cameroon & & & & & 119 & & & 116 & & 235 \\
\hline Cape Verde & & & & & 47 & & & & & 47 \\
\hline Chile & & & 677 & & 1331 & & & & & 2008 \\
\hline China & 771 & 907 & & & & & & & & 1678 \\
\hline Colombia & & & & & 1283 & & & & & 1283 \\
\hline Congo, Dem. Rep. & & & & & 149 & & & & & 149 \\
\hline Costa Rica & & & & 338 & & & & & & 338 \\
\hline Cote d'Ivoire & & & & & & & & 169 & & 169 \\
\hline Dominican Republic & & & & 110 & & & & & & 110 \\
\hline Ecuador & & 431 & & & 752 & & & & & 1183 \\
\hline Egypt, Arab Rep. & & & 956 & & & & & & & 956 \\
\hline El Salvador & & 464 & & & 904 & & & & & 1368 \\
\hline Eritrea & 57 & & & & & & & & & 57 \\
\hline Ethiopia & 303 & & & & & & & & & 303 \\
\hline Fiji & & & & & & & & 48 & & 48 \\
\hline Gambia, The & & & & & 32 & & & & & 32 \\
\hline Germany & & & & 214 & & & & & & 214 \\
\hline Ghana & & & & & & 290 & & & & 290 \\
\hline Greece & & & & 98 & & & & & & 98 \\
\hline Guatemala & & 435 & & & 641 & & & & & 1076 \\
\hline Guinea & & & & & 134 & & & & & 134 \\
\hline Guinea-Bissau & & & & & 49 & & & & & 49 \\
\hline Guyana & & & 152 & & & & & & & 152 \\
\hline
\end{tabular}

(continued on next page) 
Table A2 (continued)

\begin{tabular}{|c|c|c|c|c|c|c|c|c|c|c|}
\hline Country & 2002 & 2003 & 2004 & 2005 & 2006 & 2007 & 2008 & 2009 & 2010 & Total \\
\hline Honduras & & 446 & & & 523 & & & & & 969 \\
\hline India & 1716 & & & & 2043 & & & & & 3759 \\
\hline Indonesia & & 680 & & & & & & 1165 & & 1845 \\
\hline Ireland & & & & 175 & & & & & & 175 \\
\hline Jamaica & & & & 67 & & & & & & 67 \\
\hline Jordan & & & & & 350 & & & & & 350 \\
\hline Kenya & & 226 & & & & 392 & & & & 618 \\
\hline Korea, Rep. & & & & 215 & & & & & & 215 \\
\hline Lao PDR & & & & & 5 & & & & & 5 \\
\hline Lebanon & & & & & 161 & & & & & 161 \\
\hline Lesotho & & 55 & & & & & & & & 55 \\
\hline Madagascar & & & & 277 & & & & 203 & & 480 \\
\hline Malawi & & & & 151 & & & & & & 151 \\
\hline Malaysia & 140 & & & & & & & & & 140 \\
\hline Mali & & 70 & & & & 300 & & & & 370 \\
\hline Mauritania & & & & & 80 & & & & & 80 \\
\hline Mauritius & & & & 164 & & & & 143 & & 307 \\
\hline Mexico & & & & & 2277 & & & & & 2277 \\
\hline Mongolia & & & 185 & & & & & 131 & & 316 \\
\hline Morocco & & & 828 & & & & & & & 828 \\
\hline Mozambique & & & & & & 341 & & & & 341 \\
\hline Namibia & & & & & 104 & & & & & 104 \\
\hline Nepal & & & & & & & & 137 & & 137 \\
\hline Nicaragua & & 440 & & & 707 & & & & & 1147 \\
\hline Niger & & & & 122 & & & & & & 122 \\
\hline Nigeria & & & & & & 947 & & & & 947 \\
\hline Oman & & 97 & & & & & & & & 97 \\
\hline Pakistan & 895 & & & & & & & & & 895 \\
\hline Panama & & & & & 552 & & & & & 552 \\
\hline Paraguay & & & & & 808 & & & & & 808 \\
\hline Peru & 119 & & & & 721 & & & & & 840 \\
\hline Philippines & & 616 & & & & & & 951 & & 1567 \\
\hline Portugal & & & & 131 & & & & & & 131 \\
\hline Rwanda & & & & & 57 & & & & & 57 \\
\hline Senegal & & 140 & & & & 259 & & & & 399 \\
\hline South Africa & & 571 & & & & 679 & & & & 1250 \\
\hline Spain & & & & 134 & & & & & & 134 \\
\hline Sri Lanka & & & 367 & & & & & & & 367 \\
\hline Swaziland & & & & & 70 & & & & & 70 \\
\hline Syrian Arab Republic & & 537 & & & & & & & & 537 \\
\hline Tanzania & & 165 & & & 267 & & & & & 432 \\
\hline Thailand & & & 1381 & & & & & & & 1381 \\
\hline Turkey & 133 & & 155 & 1271 & & & 847 & & & 2406 \\
\hline Uganda & & 134 & & & 306 & & & & & 440 \\
\hline Uruguay & & & & & 756 & & & & & 756 \\
\hline Vietnam & & & & 1137 & & & & 748 & & 1885 \\
\hline Yemen, Rep. & & & & & & & & & 239 & 239 \\
\hline Zambia & 83 & & & & & 298 & & & & 381 \\
\hline Total MEs & 5554 & 8095 & 4845 & 4604 & 17,864 & 4702 & 968 & 4806 & 239 & 51,677 \\
\hline GRAND TOTAL & 6871 & 8744 & 5326 & 7989 & 17,864 & 5688 & 1849 & 7462 & 239 & 62,032 \\
\hline
\end{tabular}


Table A3

Partialling-out regressions.

The table below reports the basic results for the first-step fixed effects estimates of Eq. (12). Fixed effects correspond to country surveys. Each public input is estimated separately for market economies (ME), planned economies (PE) for the period 2002-05 (BEEPS II \& III), and planned economies for 2008 (BEEPS IV). Standard errors are in parentheses; they are reported for information only and are not used for the tests in the paper. Bold and italic indicates significant at the 5\% level. The constant column reports the estimated mean fixed effect.

\begin{tabular}{|c|c|c|c|c|c|c|c|c|}
\hline Constraint & Country group & $\log (\mathrm{N})$ & foreign & exporter & importer & constant & $\mathrm{N}$ (obs) & $\mathrm{N}$ (surveys) \\
\hline \multirow[t]{3}{*}{ Access Land } & ME & $\begin{array}{r}-0.0440 \\
(0.0045)\end{array}$ & $\begin{array}{r}-\mathbf{0 . 0 7 6 6} \\
(0.0182)\end{array}$ & $\begin{array}{r}0.0114 \\
(0.0135)\end{array}$ & $\begin{array}{r}\mathbf{0 . 0 9 5 4} \\
(0.0147)\end{array}$ & $\begin{array}{r}\mathbf{0 . 8 3 1 0} \\
(0.0070)\end{array}$ & 49,018 & 111 \\
\hline & PE 2002-05 & $\begin{array}{r}-0.0414 \\
(0.0099)\end{array}$ & $\begin{array}{r}\mathbf{0 . 0 9 9 2} \\
(0.0399)\end{array}$ & $\begin{array}{r}-0.0292 \\
(0.0341)\end{array}$ & $\begin{array}{l}-0.0091 \\
(0.0344)\end{array}$ & $\begin{array}{r}\mathbf{0 . 6 6 8 8} \\
(0.0196)\end{array}$ & 5386 & 61 \\
\hline & PE 2008 & $\begin{array}{c}-0.0354 \\
(0.0174)\end{array}$ & $\begin{array}{r}-0.0991 \\
(0.0670)\end{array}$ & $\begin{array}{r}-0.0857 \\
(0.0520)\end{array}$ & $\begin{array}{r}\mathbf{0 . 1 4 6 1} \\
(0.0505)\end{array}$ & $\begin{array}{r}1.1486 \\
(0.0296)\end{array}$ & 4149 & 28 \\
\hline \multirow[t]{3}{*}{ Bus Licensing } & $\mathrm{ME}$ & $\begin{array}{r}0.0047 \\
(0.0044)\end{array}$ & $\begin{array}{c}-0.0347 \\
(0.0176)\end{array}$ & $\begin{array}{r}0.0077 \\
(0.0131)\end{array}$ & $\begin{array}{r}0.2527 \\
(0.0144)\end{array}$ & $\begin{array}{r}\mathbf{0 . 8 7 0 7} \\
(0.0068)\end{array}$ & 49,170 & 110 \\
\hline & PE 2002-05 & $\begin{array}{l}-0.0027 \\
(0.0106)\end{array}$ & $\begin{array}{r}\mathbf{0 . 0 8 6 6} \\
(0.0425)\end{array}$ & $\begin{array}{r}0.0175 \\
(0.0363)\end{array}$ & $\begin{array}{r}0.0608 \\
(0.0368)\end{array}$ & $\begin{array}{r}1.0140 \\
(0.0209)\end{array}$ & 5577 & 61 \\
\hline & PE 2008 & $\begin{array}{r}0.0206 \\
(0.0152)\end{array}$ & $\begin{array}{r}0.0416 \\
(0.0589)\end{array}$ & $\begin{array}{r}0.0107 \\
(0.0459)\end{array}$ & $\begin{array}{r}0.0455 \\
(0.0447)\end{array}$ & $\begin{array}{r}1.1187 \\
(0.0259)\end{array}$ & 4226 & 28 \\
\hline \multirow[t]{3}{*}{ Corruption } & $\mathrm{ME}$ & $\begin{array}{r}-\mathbf{0 . 0 2 6 1} \\
(0.0055)\end{array}$ & $\begin{array}{c}-0.0729 \\
(0.0220)\end{array}$ & $\begin{array}{r}0.0029 \\
(0.0163)\end{array}$ & $\begin{array}{r}\mathbf{0 . 4 6 0 7} \\
(0.0178)\end{array}$ & $\begin{array}{r}1.4917 \\
(0.0085)\end{array}$ & 49,490 & 111 \\
\hline & PE 2002-05 & $\begin{array}{l}-0.0060 \\
(0.0117)\end{array}$ & $\begin{array}{l}-0.0165 \\
(0.0470)\end{array}$ & $\begin{array}{r}-0.0347 \\
(0.0406)\end{array}$ & $\begin{array}{r}0.0638 \\
(0.0402)\end{array}$ & $\begin{array}{r}1.2853 \\
(0.0233)\end{array}$ & 5108 & 60 \\
\hline & PE 2008 & $\begin{array}{l}-0.0229 \\
(0.0172)\end{array}$ & $\begin{array}{r}-0.0693 \\
(0.0674)\end{array}$ & $\begin{array}{r}0.0089 \\
(0.0519)\end{array}$ & $\begin{array}{r}0.0532 \\
(0.0507)\end{array}$ & $\begin{array}{r}1.7155 \\
(0.0295)\end{array}$ & 4246 & 28 \\
\hline \multirow[t]{3}{*}{ Courts } & ME & $\begin{array}{r}\mathbf{0 . 0 3 6 6} \\
(0.0049)\end{array}$ & $\begin{array}{c}-0.0296 \\
(0.0195)\end{array}$ & $\begin{array}{r}0.0097 \\
(0.0145)\end{array}$ & $\begin{array}{r}\mathbf{0 . 3 0 3 6} \\
(0.0151)\end{array}$ & $\begin{array}{r}\mathbf{0 . 7 9 2 4} \\
(0.0077)\end{array}$ & 39,360 & 95 \\
\hline & PE 2002-05 & $\begin{array}{r}0.0427 \\
(0.0110)\end{array}$ & $\begin{array}{r}0.0073 \\
(0.0442)\end{array}$ & $\begin{array}{c}-0.0928 \\
(0.0376)\end{array}$ & $\begin{array}{r}0.0695 \\
(0.0382)\end{array}$ & $\begin{array}{r}1.1892 \\
(0.0217)\end{array}$ & 5352 & 61 \\
\hline & PE 2008 & $\begin{array}{r}0.0169 \\
(0.0164)\end{array}$ & $\begin{array}{r}0.0270 \\
(0.0641)\end{array}$ & $\begin{array}{r}0.0032 \\
(0.0493)\end{array}$ & $\begin{array}{r}0.0865 \\
(0.0482)\end{array}$ & $\begin{array}{r}1.2939 \\
(0.0284)\end{array}$ & 4096 & 28 \\
\hline \multirow[t]{3}{*}{ Crime Theft Disorder } & $\mathrm{ME}$ & $\begin{array}{r}-0.0032 \\
(0.0048)\end{array}$ & $\begin{array}{c}-0.0394 \\
(0.0190)\end{array}$ & $\begin{array}{r}-0.0568 \\
(0.0142)\end{array}$ & $\begin{array}{r}0.2593 \\
(0.0156)\end{array}$ & $\begin{array}{r}1.1212 \\
(0.0074)\end{array}$ & 48,019 & 108 \\
\hline & PE 2002-05 & $\begin{array}{r}-0.0283 \\
(0.0102)\end{array}$ & $\begin{array}{c}-0.0132 \\
(0.0412)\end{array}$ & $\begin{array}{r}-0.0423 \\
(0.0351)\end{array}$ & $\begin{array}{r}0.0203 \\
(0.0358)\end{array}$ & $\begin{array}{r}0.9505 \\
(0.0202)\end{array}$ & 5521 & 61 \\
\hline & PE 2008 & $\begin{array}{c}-0.0118 \\
(0.0159)\end{array}$ & $\begin{array}{r}-0.1070 \\
(0.0620)\end{array}$ & $\begin{array}{r}-0.0625 \\
(0.0481)\end{array}$ & $\begin{array}{l}-0.0431 \\
(0.0469)\end{array}$ & $\begin{array}{r}1.3317 \\
(0.0271)\end{array}$ & 4407 & 28 \\
\hline \multirow[t]{3}{*}{ Customs } & ME & $\begin{array}{r}\mathbf{0 . 0 5 1 6} \\
(0.0045)\end{array}$ & $\begin{array}{r}\mathbf{0 . 0 8 8 7} \\
(0.0176)\end{array}$ & $\begin{array}{r}\mathbf{0 . 2 0 3 1} \\
(0.0132)\end{array}$ & $\begin{array}{r}\mathbf{0 . 6 8 7 3} \\
(0.0143)\end{array}$ & $\begin{array}{r}\mathbf{0 . 7 1 0 7} \\
(0.0071)\end{array}$ & 46,453 & 110 \\
\hline & PE 2002-05 & $\begin{array}{r}0.0386 \\
(0.0109)\end{array}$ & $\begin{array}{r}\text { 0.1272 } \\
(0.0430)\end{array}$ & $\begin{array}{r}0.2779 \\
(0.0368)\end{array}$ & $\begin{array}{r}0.3171 \\
(0.0373)\end{array}$ & $\begin{array}{r}0.9504 \\
(0.0219)\end{array}$ & 5306 & 61 \\
\hline & PE 2008 & $\begin{array}{r}0.0137 \\
(0.0157)\end{array}$ & $\begin{array}{r}0.0969 \\
(0.0596)\end{array}$ & $\begin{array}{r}0.1932 \\
(0.0459)\end{array}$ & $\begin{array}{r}0.3608 \\
(0.0447)\end{array}$ & $\begin{array}{r}0.7666 \\
(0.0280)\end{array}$ & 3923 & 28 \\
\hline \multirow[t]{3}{*}{ Electricity } & ME & $\begin{array}{c}-\mathbf{0 . 0 1 1 4} \\
(0.0052)\end{array}$ & $\begin{array}{r}-0.0188 \\
(0.0209)\end{array}$ & $\begin{array}{r}0.0187 \\
(0.0155)\end{array}$ & $\begin{array}{r}\mathbf{0 . 3 1 6 6} \\
(0.0169)\end{array}$ & $\begin{array}{r}1.4811 \\
(0.0080)\end{array}$ & 50,166 & 111 \\
\hline & PE 2002-05 & $\begin{array}{c}-0.0074 \\
(0.0090)\end{array}$ & $\begin{array}{c}-0.0064 \\
(0.0363)\end{array}$ & $\begin{array}{r}-0.0129 \\
(0.0309)\end{array}$ & $\begin{array}{r}-0.0502 \\
(0.0314)\end{array}$ & $\begin{array}{r}\mathbf{0 . 6 6 8 3} \\
(0.0177)\end{array}$ & 5798 & 61 \\
\hline & PE 2008 & $\begin{array}{r}0.0140 \\
(0.0187)\end{array}$ & $\begin{array}{r}-0.1087 \\
(0.0731)\end{array}$ & $\begin{array}{c}-0.0614 \\
(0.0567)\end{array}$ & $\begin{array}{r}0.0793 \\
(0.0554)\end{array}$ & $\begin{array}{r}1.7045 \\
(0.0318)\end{array}$ & 4489 & 28 \\
\hline \multirow[t]{2}{*}{ Gov Policy Unc } & $\mathrm{ME}$ & $\begin{array}{r}\text { 0.0470 } \\
(0.0065)\end{array}$ & $\begin{array}{r}-0.0090 \\
(0.0271)\end{array}$ & $\begin{array}{c}-0.0144 \\
(0.0192)\end{array}$ & $\begin{array}{r}\mathbf{0 . 0 7 6 0} \\
(0.0233)\end{array}$ & $\begin{array}{r}1.5636 \\
(0.0103)\end{array}$ & 25,936 & 62 \\
\hline & PE 2002-05 & $\begin{array}{r}\mathbf{0 . 0 2 1 1} \\
(0.0104)\end{array}$ & $\begin{array}{r}-0.0590 \\
(0.0417)\end{array}$ & $\begin{array}{c}-0.0038 \\
(0.0354)\end{array}$ & $\begin{array}{r}0.0449 \\
(0.0362)\end{array}$ & $\begin{array}{r}1.7747 \\
(0.0204)\end{array}$ & 5667 & 61 \\
\hline \multirow[t]{3}{*}{ Inad Educ Labor } & ME & $\begin{array}{r}\mathbf{0 . 0 3 7 4} \\
(0.0046)\end{array}$ & $\begin{array}{r}-0.1078 \\
(0.0186)\end{array}$ & $\begin{array}{r}0.0072 \\
(0.0137)\end{array}$ & $\begin{array}{r}\mathbf{0 . 3 6 8 6} \\
(0.0150)\end{array}$ & $\begin{array}{r}1.1018 \\
(0.0071)\end{array}$ & 49,986 & 111 \\
\hline & PE 2002-05 & $\begin{array}{r}0.0230 \\
(0.0103)\end{array}$ & $\begin{array}{r}0.0441 \\
(0.0415)\end{array}$ & $\begin{array}{r}\mathbf{0 . 1 1 5 6} \\
(0.0353)\end{array}$ & $\begin{array}{r}\mathbf{0 . 0 8 4 0} \\
(0.0360)\end{array}$ & $\begin{array}{r}1.0131 \\
(0.0203)\end{array}$ & 5706 & 61 \\
\hline & PE 2008 & $\begin{array}{r}\mathbf{0 . 0 5 9 8} \\
(0.0157)\end{array}$ & $\begin{array}{c}-0.0514 \\
(0.0613)\end{array}$ & $\begin{array}{r}\mathbf{0 . 1 4 9 1} \\
(0.0476)\end{array}$ & $\begin{array}{r}\mathbf{0 . 0 9 4 5} \\
(0.0465)\end{array}$ & $\begin{array}{r}1.7181 \\
(0.0268)\end{array}$ & 4438 & 28 \\
\hline \multirow[t]{3}{*}{ Labor Reg } & ME & $\begin{array}{r}\mathbf{0 . 0 5 3 2} \\
(0.0043)\end{array}$ & $\begin{array}{c}-0.0648 \\
(0.0174)\end{array}$ & $\begin{array}{r}\mathbf{0 . 0 5 4 0} \\
(0.0129)\end{array}$ & $\begin{array}{r}\mathbf{0 . 2 6 7 3} \\
(0.0141)\end{array}$ & $\begin{array}{r}0.9213 \\
(0.0067)\end{array}$ & 49,603 & 110 \\
\hline & PE 2002-05 & $\begin{array}{r}0.0445 \\
(0.0096)\end{array}$ & $\begin{array}{r}0.0087 \\
(0.0387)\end{array}$ & $\begin{array}{r}\mathbf{0 . 0 9 3 4} \\
(0.0329)\end{array}$ & $\begin{array}{r}0.0234 \\
(0.0335)\end{array}$ & $\begin{array}{r}0.9396 \\
(0.0190)\end{array}$ & 5653 & 61 \\
\hline & PE 2008 & $\begin{array}{r}\mathbf{0 . 0 4 7 5} \\
(0.0134)\end{array}$ & $\begin{array}{r}-0.0285 \\
(0.0524)\end{array}$ & $\begin{array}{r}\mathbf{0 . 1 1 9 7} \\
(0.0406)\end{array}$ & $\begin{array}{r}\mathbf{0 . 0 9 4 0} \\
(0.0398)\end{array}$ & $\begin{array}{r}\mathbf{0 . 9 6 7 8} \\
(0.0228)\end{array}$ & 4475 & 28 \\
\hline \multirow[t]{2}{*}{ Macro Instability } & $\mathrm{ME}$ & $\begin{array}{r}0.0388 \\
(0.0063)\end{array}$ & $\begin{array}{c}-0.0565 \\
(0.0248)\end{array}$ & $\begin{array}{r}0.1077 \\
(0.0182)\end{array}$ & $\begin{array}{r}0.0612 \\
(0.0199)\end{array}$ & $\begin{array}{r}1.8746 \\
(0.0100)\end{array}$ & 31,781 & 85 \\
\hline & PE 2002-05 & $\begin{array}{r}\mathbf{0 . 0 2 6 8} \\
(0.0104)\end{array}$ & $\begin{array}{c}-0.0144 \\
(0.0418)\end{array}$ & $\begin{array}{r}\mathbf{0 . 0 7 8 2} \\
(0.0356)\end{array}$ & $\begin{array}{r}0.0355 \\
(0.0363)\end{array}$ & $\begin{array}{r}1.7325 \\
(0.0205)\end{array}$ & 5674 & 61 \\
\hline Political Instability & ME & $\begin{array}{r}0.0108 \\
(0.0078)\end{array}$ & $\begin{array}{r}-0.0413 \\
(0.0303)\end{array}$ & $\begin{array}{r}\mathbf{0 . 0 8 6 1} \\
(0.0237)\end{array}$ & $\begin{array}{r}\mathbf{0 . 0 5 9 1} \\
(0.0227)\end{array}$ & $\begin{array}{r}1.6045 \\
(0.0121)\end{array}$ & 18,473 & 51 \\
\hline
\end{tabular}

(continued on next page) 
Table A3 (continued)

\begin{tabular}{|c|c|c|c|c|c|c|c|c|}
\hline Constraint & Country group & $\log (\mathrm{N})$ & foreign & exporter & importer & constant & $\mathrm{N}$ (obs) & $\mathrm{N}$ (surveys) \\
\hline & PE 2008 & $\begin{array}{r}0.0197 \\
(0.0169)\end{array}$ & $\begin{array}{c}-0.0754 \\
(0.0663)\end{array}$ & $\begin{array}{r}0.0698 \\
(0.0511)\end{array}$ & $\begin{array}{c}-0.0866 \\
(0.0499)\end{array}$ & $\begin{array}{r}1.8372 \\
(0.0290)\end{array}$ & 4328 & 28 \\
\hline \multirow[t]{3}{*}{ Tax Administration } & $\mathrm{ME}$ & $\begin{array}{r}0.0009 \\
(0.0048)\end{array}$ & $\begin{array}{r}-\mathbf{0 . 0 6 1 3} \\
(0.0193)\end{array}$ & $\begin{array}{r}0.0040 \\
(0.0143)\end{array}$ & $\begin{array}{r}0.3462 \\
(0.0157)\end{array}$ & $\begin{array}{r}1.3101 \\
(0.0074)\end{array}$ & 49,611 & 110 \\
\hline & PE 2002-05 & $\begin{array}{l}-0.0123 \\
(0.0106)\end{array}$ & $\begin{array}{r}0.0200 \\
(0.0426)\end{array}$ & $\begin{array}{r}0.0291 \\
(0.0363)\end{array}$ & $\begin{array}{r}\mathbf{0 . 0 7 9 3} \\
(0.0370)\end{array}$ & $\begin{array}{r}\mathbf{1 . 5 7 8 4} \\
(0.0208)\end{array}$ & 5690 & 61 \\
\hline & PE 2008 & $\begin{array}{r}0.0096 \\
(0.0151)\end{array}$ & $\begin{array}{r}-0.0013 \\
(0.0590)\end{array}$ & $\begin{array}{r}0.1112 \\
(0.0459)\end{array}$ & $\begin{array}{r}0.0409 \\
(0.0448)\end{array}$ & $\begin{array}{r}1.4997 \\
(0.0258)\end{array}$ & 4464 & 28 \\
\hline \multirow[t]{2}{*}{ Telecoms } & $\mathrm{ME}$ & $\begin{array}{r}\mathbf{0 . 0 2 7 3} \\
(0.0052)\end{array}$ & $\begin{array}{r}0.0952 \\
(0.0205)\end{array}$ & $\begin{array}{r}\mathbf{0 . 0 5 1 9} \\
(0.0155)\end{array}$ & $\begin{array}{r}0.0239 \\
(0.0173)\end{array}$ & $\begin{array}{r}\mathbf{0 . 6 8 2 2} \\
(0.0081)\end{array}$ & 30,617 & 85 \\
\hline & PE 2002-05 & $\begin{array}{r}-0.0133 \\
(0.0079)\end{array}$ & $\begin{array}{r}0.0097 \\
(0.0318)\end{array}$ & $\begin{array}{r}0.0157 \\
(0.0272)\end{array}$ & $\begin{array}{l}-0.0057 \\
(0.0276)\end{array}$ & $\begin{array}{r}\mathbf{0 . 4 6 6 8} \\
(0.0156)\end{array}$ & 5728 & 61 \\
\hline \multirow[t]{3}{*}{ Transport } & $\mathrm{ME}$ & $\begin{array}{r}\mathbf{0 . 0 2 4 3} \\
(0.0044)\end{array}$ & $\begin{array}{r}0.0242 \\
(0.0177)\end{array}$ & $\begin{array}{r}0.0111 \\
(0.0131)\end{array}$ & $\begin{array}{r}\mathbf{0 . 2 9 5 1} \\
(0.0143)\end{array}$ & $\begin{array}{r}\mathbf{0 . 8 8 0 3} \\
(0.0068)\end{array}$ & 49,680 & 110 \\
\hline & PE 2002-05 & $\begin{array}{r}0.0079 \\
(0.0087)\end{array}$ & $\begin{array}{r}\mathbf{0 . 0 7 2 2} \\
(0.0350)\end{array}$ & $\begin{array}{r}0.0015 \\
(0.0299)\end{array}$ & $\begin{array}{r}0.0119 \\
(0.0303)\end{array}$ & $\begin{array}{r}0.5706 \\
(0.0171)\end{array}$ & 5772 & 61 \\
\hline & PE 2008 & $\begin{array}{r}\mathbf{0 . 0 3 6 8} \\
(0.0161)\end{array}$ & $\begin{array}{r}0.0644 \\
(0.0628)\end{array}$ & $\begin{array}{l}-0.0313 \\
(0.0487)\end{array}$ & $\begin{array}{r}0.0749 \\
(0.0476)\end{array}$ & $\begin{array}{r}1.1078 \\
(0.0274)\end{array}$ & 4448 & 28 \\
\hline
\end{tabular}

Table A4

Second-step estimations.

This table reports the results for the second-step estimates of Eq. (13). Each public input is estimated twice, first pooling market economies with planned economies for the period 2002-05 (BEEPS II \& III), and second pooling the same sample for 2008 (BEEPS IV). Heteroskedastic-robust standard errors are in parentheses. Cross-equation tests are based on pooling these separate estimations using the Stata command suest, clustering on firm, and are not reported here. Bold and italic indicates significant at the 5\% level. GDP per capita $\bar{A}_{j}$ is centred at the $\ln (\$ 7500)$, the middle of the PE range for the period and sample of countries we have. The constant column can be interpreted as the estimated mean reported cost of input $k$ for a ME with this level of income, and the coefficient on the dummy variable $P L A N_{\mathrm{j}}$ is an estimate of the difference between reported costs in a planned economy compared to a market economy, holding income constant at this level.

\begin{tabular}{|c|c|c|c|c|c|c|c|c|c|}
\hline \multirow[b]{3}{*}{ Constraint } & \multirow[b]{3}{*}{ Comparison } & \multirow{2}{*}{$\frac{\text { Low income }}{\text { intercept }}$} & \multirow{2}{*}{$\frac{\text { Low income }}{\mathrm{PE}}$} & \multirow{2}{*}{$\frac{\text { High income }}{\text { intercept }}$} & \multicolumn{5}{|l|}{ High income } \\
\hline & & & & & \multirow{2}{*}{$\frac{P E}{\delta_{2}}$} & \multirow{2}{*}{$\frac{\log (\mathrm{GDP})}{\delta_{1}}$} & \multirow{2}{*}{$\frac{\log (\mathrm{GDP})^{*} \mathrm{PE}}{\delta_{3}}$} & \multirow[b]{2}{*}{$\mathrm{N}$ obs } & \multirow[b]{2}{*}{$\mathrm{N}$ countries } \\
\hline & & $\delta_{0}$ & $\delta_{2}$ & $\delta_{0}$ & & & & & \\
\hline Access Land & ME vs. PE 2002-05 & $\begin{array}{r}0.879 \\
(0.006)\end{array}$ & $\begin{array}{r}-0.177 \\
(0.019)\end{array}$ & $\begin{array}{r}0.412 \\
(0.010)\end{array}$ & $\begin{array}{r}0.217 \\
(0.022)\end{array}$ & $\begin{array}{r}-0.302 \\
(0.077)\end{array}$ & $\begin{array}{r}0.255 \\
(0.099)\end{array}$ & 54,404 & 110 \\
\hline & ME vs. PE 2008 & & $\begin{array}{r}0.374 \\
(0.044)\end{array}$ & & $\begin{array}{r}\mathbf{0 . 6 8 1} \\
(0.031)\end{array}$ & & $\begin{array}{r}0.198 \\
(0.198)\end{array}$ & 53,167 & 109 \\
\hline Bus Licensing & ME vs. PE 2002-05 & $\begin{array}{r}0.879 \\
(0.006)\end{array}$ & $\begin{array}{r}0.204 \\
(0.021)\end{array}$ & $\begin{array}{r}0.797 \\
(0.010)\end{array}$ & $\begin{array}{r}0.137 \\
(0.024)\end{array}$ & $\begin{array}{r}-0.053 \\
(0.080)\end{array}$ & $\begin{array}{r}-0.043 \\
(0.112)\end{array}$ & 54,747 & 110 \\
\hline & ME vs. PE 2008 & & $\begin{array}{r}0.263 \\
(0.036)\end{array}$ & & $\begin{array}{r}0.309 \\
(0.027)\end{array}$ & & $\begin{array}{r}0.029 \\
(0.128)\end{array}$ & 53,396 & 109 \\
\hline Corruption & ME vs. PE 2002-05 & $\begin{array}{r}1.524 \\
(0.007)\end{array}$ & $\begin{array}{c}-0.135 \\
(0.025)\end{array}$ & $\begin{array}{r}1.206 \\
(0.013)\end{array}$ & $\begin{array}{l}-0.040 \\
(0.027)\end{array}$ & $\begin{array}{c}-0.205 \\
(0.108)\end{array}$ & $\begin{array}{r}0.061 \\
(0.154)\end{array}$ & 54,598 & 110 \\
\hline & ME vs. PE 2008 & & $\begin{array}{r}0.418 \\
(0.047)\end{array}$ & & $\begin{array}{r}\mathbf{0 . 3 8 8} \\
(0.032)\end{array}$ & & $\begin{array}{r}-0.020 \\
(0.210)\end{array}$ & 53,736 & 109 \\
\hline Courts & ME vs. PE 2002-05 & $\begin{array}{r}\mathbf{0 . 7 9 7} \\
(0.007)\end{array}$ & $\begin{array}{r}0.346 \\
(0.022)\end{array}$ & $\begin{array}{r}0.771 \\
(0.011)\end{array}$ & $\begin{array}{r}0.469 \\
(0.026)\end{array}$ & $\begin{array}{r}-0.017 \\
(0.091)\end{array}$ & $\begin{array}{r}0.080 \\
(0.155)\end{array}$ & 44,712 & 100 \\
\hline & ME vs. PE 2008 & & $\begin{array}{r}0.538 \\
(0.043)\end{array}$ & & $\begin{array}{r}0.502 \\
(0.029)\end{array}$ & & $\begin{array}{l}-0.023 \\
(0.145)\end{array}$ & 43,456 & 99 \\
\hline Crime, Theft, Disord & ME vs. PE 2002-05 & $\begin{array}{r}1.137 \\
(0.006)\end{array}$ & $\begin{array}{r}-0.192 \\
(0.021)\end{array}$ & $\begin{array}{r}0.975 \\
(0.011)\end{array}$ & $\begin{array}{l}-0.018 \\
(0.025)\end{array}$ & $\begin{array}{r}-0.105 \\
(0.087)\end{array}$ & $\begin{array}{r}0.112 \\
(0.149)\end{array}$ & 53,540 & 107 \\
\hline & ME vs. PE 2008 & & $\begin{array}{r}0.513 \\
(0.044)\end{array}$ & & $\begin{array}{r}0.185 \\
(0.028)\end{array}$ & & $\begin{array}{r}-0.211 \\
(0.160)\end{array}$ & 52,426 & 106 \\
\hline
\end{tabular}


Table A4 (continued)

\begin{tabular}{|c|c|c|c|c|c|c|c|c|c|}
\hline \multirow[b]{3}{*}{ Constraint } & \multirow[b]{3}{*}{ Comparison } & \multirow{2}{*}{$\frac{\text { Low income }}{\text { intercept }}$} & \multirow{2}{*}{$\frac{\text { Low income }}{\mathrm{PE}}$} & \multirow{2}{*}{$\frac{\text { High income }}{\text { intercept }}$} & \multicolumn{5}{|l|}{ High income } \\
\hline & & & & & \multirow{2}{*}{$\frac{\mathrm{PE}}{\delta_{2}}$} & \multirow{2}{*}{$\frac{\log (\mathrm{GDP})}{\delta_{1}}$} & \multirow{2}{*}{$\frac{\log (\mathrm{GDP})^{*} \mathrm{PE}}{\delta_{3}}$} & \multirow[b]{2}{*}{$\mathrm{N}$ obs } & \multirow[b]{2}{*}{$\mathrm{N}$ countries } \\
\hline & & $\delta_{0}$ & $\delta_{2}$ & $\delta_{0}$ & & & & & \\
\hline \multirow[t]{2}{*}{ Customs } & ME vs. PE 2002-05 & $\begin{array}{r}\mathbf{0 . 7 3 8} \\
(0.006)\end{array}$ & $\begin{array}{r}\mathbf{0 . 3 4 5} \\
(0.022)\end{array}$ & $\begin{array}{r}\mathbf{0 . 4 4 8} \\
(0.010)\end{array}$ & $\begin{array}{r}\mathbf{0 . 3 5 1} \\
(0.024)\end{array}$ & $\begin{array}{c}-\mathbf{0 . 1 8 7} \\
(0.069)\end{array}$ & $\begin{array}{r}0.004 \\
(0.107)\end{array}$ & 51,759 & 110 \\
\hline & ME vs. PE 2008 & & $\begin{array}{r}0.291 \\
(0.041)\end{array}$ & & $\begin{array}{r}0.181 \\
(0.027)\end{array}$ & & $\begin{array}{c}-0.071 \\
(0.121)\end{array}$ & 50,376 & 109 \\
\hline \multirow[t]{2}{*}{ Electricity } & ME vs. PE 2002-05 & $\begin{array}{r}1.567 \\
(0.007)\end{array}$ & $\begin{array}{r}-0.798 \\
(0.020)\end{array}$ & $\begin{array}{r}\mathbf{0 . 7 0 8} \\
(0.012)\end{array}$ & $\begin{array}{c}-0.158 \\
(0.022)\end{array}$ & $\begin{array}{c}-\mathbf{0 . 5 5 4} \\
(0.075)\end{array}$ & $\begin{array}{r}\mathbf{0 . 4 1 3} \\
(0.112)\end{array}$ & 55,964 & 110 \\
\hline & ME vs. PE 2008 & & $\begin{array}{r}\mathbf{0 . 4 1 4} \\
(0.045)\end{array}$ & & $\begin{array}{r}0.846 \\
(0.034)\end{array}$ & & $\begin{array}{r}0.279 \\
(0.161)\end{array}$ & 54,655 & 109 \\
\hline \multirow[t]{2}{*}{ Gov Policy Unc } & ME vs. PE 2002-05 & $\begin{array}{r}1.574 \\
(0.009)\end{array}$ & $\begin{array}{r}\mathbf{0 . 1 8 2} \\
(0.022)\end{array}$ & $\begin{array}{r}1.455 \\
(0.017)\end{array}$ & $\begin{array}{r}0.342 \\
(0.028)\end{array}$ & $\begin{array}{r}-0.077 \\
(0.156)\end{array}$ & $\begin{array}{r}0.103 \\
(0.193)\end{array}$ & 31,603 & 79 \\
\hline & ME vs. PE 2008 & & & & & & & n.a. & n.a. \\
\hline \multirow[t]{2}{*}{ Inad Educ Labor } & ME vs. PE 2002-05 & $\begin{array}{r}1.100 \\
(0.006)\end{array}$ & $\begin{array}{r}-\mathbf{0 . 2 0 6} \\
(0.019)\end{array}$ & $\begin{array}{r}\mathbf{1 . 1 2 0} \\
(0.011)\end{array}$ & $\begin{array}{r}0.030 \\
(0.024)\end{array}$ & $\begin{array}{r}0.013 \\
(0.082)\end{array}$ & $\begin{array}{r}0.152 \\
(0.104)\end{array}$ & 55,692 & 110 \\
\hline & ME vs. PE 2008 & & $\begin{array}{r}\mathbf{0 . 7 0 5} \\
(0.040)\end{array}$ & & $\begin{array}{r}\mathbf{0 . 5 5 1} \\
(0.029)\end{array}$ & & $\begin{array}{l}-0.099 \\
(0.159)\end{array}$ & 54,424 & 109 \\
\hline \multirow[t]{2}{*}{ Labor Reg } & ME vs. PE 2002-05 & $\begin{array}{r}\mathbf{0 . 9 0 4} \\
(0.005)\end{array}$ & $\begin{array}{r}-\mathbf{0 . 1 6 4} \\
(0.017)\end{array}$ & $\begin{array}{r}\mathbf{1 . 0 7 1} \\
(0.011)\end{array}$ & $\begin{array}{r}\mathbf{0 . 0 9 3} \\
(0.024)\end{array}$ & $\begin{array}{r}0.108 \\
(0.094)\end{array}$ & $\begin{array}{r}0.166 \\
(0.127)\end{array}$ & 55,256 & 110 \\
\hline & ME vs. PE 2008 & & $\begin{array}{r}-0.155 \\
(0.031)\end{array}$ & & $\begin{array}{r}0.016 \\
(0.025)\end{array}$ & & $\begin{array}{r}0.110 \\
(0.121)\end{array}$ & 54,078 & 109 \\
\hline \multirow[t]{2}{*}{ Macro Instability } & ME vs. PE 2002-05 & $\begin{array}{r}1.856 \\
(0.008)\end{array}$ & $\begin{array}{c}-0.092 \\
(0.022)\end{array}$ & $\begin{array}{r}2.052 \\
(0.015)\end{array}$ & $\begin{array}{c}-0.356 \\
(0.027)\end{array}$ & $\begin{array}{r}0.127 \\
(0.114)\end{array}$ & $\begin{array}{l}-0.170 \\
(0.155)\end{array}$ & 37,455 & 100 \\
\hline & ME vs. PE 2008 & & & & & & & n.a. & n.a. \\
\hline \multirow[t]{2}{*}{ Political Instability } & ME vs. PE 2002-05 & & & & & & & n.a. & n.a. \\
\hline & ME vs. PE 2008 & $\begin{array}{r}1.596 \\
(0.011)\end{array}$ & $\begin{array}{r}\mathbf{0 . 4 4 9} \\
(0.047)\end{array}$ & $\begin{array}{r}1.847 \\
(0.020)\end{array}$ & $\begin{array}{c}-\mathbf{0 . 1 2 0} \\
(0.036)\end{array}$ & $\begin{array}{r}0.162 \\
(0.168)\end{array}$ & $\begin{array}{l}-0.367 \\
(0.262)\end{array}$ & 22,801 & 78 \\
\hline \multirow[t]{2}{*}{ Tax Administration } & ME vs. PE 2002-05 & $\begin{array}{r}1.340 \\
(0.006)\end{array}$ & $\begin{array}{r}\mathbf{0 . 3 0 0} \\
(0.021)\end{array}$ & $\begin{array}{r}\mathbf{1 . 0 4 4} \\
(0.012)\end{array}$ & $\begin{array}{r}\mathbf{0 . 4 6 3} \\
(0.026)\end{array}$ & $\begin{array}{r}-0.190 \\
(0.111)\end{array}$ & $\begin{array}{r}0.105 \\
(0.151)\end{array}$ & 55,301 & 110 \\
\hline & ME vs. PE 2008 & & $\begin{array}{r}\mathbf{0 . 1 0 1} \\
(0.038)\end{array}$ & & $\begin{array}{r}0.487 \\
(0.028)\end{array}$ & & $\begin{array}{r}0.249 \\
(0.147)\end{array}$ & 54,075 & 109 \\
\hline \multirow[t]{2}{*}{ Telecoms } & ME vs. PE 2002-05 & $\begin{array}{r}\mathbf{0 . 6 7 2} \\
(0.006)\end{array}$ & $\begin{array}{r}-\mathbf{0 . 1 8 0} \\
(0.016)\end{array}$ & $\begin{array}{r}\mathbf{0 . 4 1 8} \\
(0.012)\end{array}$ & $\begin{array}{r}0.020 \\
(0.020)\end{array}$ & $\begin{array}{r}-\mathbf{0 . 1 6 3} \\
(0.047)\end{array}$ & $\begin{array}{r}0.129 \\
(0.067)\end{array}$ & 36,345 & 99 \\
\hline & ME vs. PE 2008 & & & & & & & n.a. & n.a. \\
\hline \multirow[t]{2}{*}{ Transport } & ME vs. PE 2002-05 & $\begin{array}{r}0.918 \\
(0.006)\end{array}$ & $\begin{array}{r}-0.352 \\
(0.017)\end{array}$ & $\begin{array}{r}\mathbf{0 . 5 3 8} \\
(0.010)\end{array}$ & $\begin{array}{r}0.038 \\
(0.020)\end{array}$ & $\begin{array}{r}-\mathbf{0 . 2 4 5} \\
(0.050)\end{array}$ & $\begin{array}{r}\mathbf{0 . 2 5 1} \\
(0.070)\end{array}$ & 55,452 & 109 \\
\hline & ME vs. PE 2008 & & $\begin{array}{r}0.239 \\
(0.039)\end{array}$ & & $\begin{array}{r}0.543 \\
(0.028)\end{array}$ & & $\begin{array}{r}0.196 \\
(0.112)\end{array}$ & 54,128 & 108 \\
\hline
\end{tabular}

Notes:

Coefficients are obtained from estimation of Eq. (13) in the main text.

Intercepts and SEs for "ME vs. PE 2008" are identical to "ME vs. PE 2002-05" and hence are not shown.

SEs for intercepts and PE dummies are robust to heteroskedasticity.

SEs for GDP terms are robust to heteroskedasticity and clustering on country.

\section{A.2.1. Tables A5 and A6. Ranking of constraints}

Tables A5 and A6 present the analysis of the ranking of constraints for each country group based on the tests of the differences between the reported costs of constraints. The diagonals show the estimated $\widehat{\delta}_{3 k}$ in Eq. (13) for obstacle $k$ in a particular country group. The row/column off-diagonals report the results of testing whether, for a given country group, the estimated $\widehat{\delta}_{3 k}$ for the row obstacle $k$ is significantly different from the $\widehat{\delta}_{3 q}$ estimated for the column obstacle $q$. To facilitate comparison of ranks across the country groups, we have used italic font for the physical infrastructure elements (shaded blue), under-lined access to skilled labour (yellow), macroeconomic constraints are bold (pink) and institutions are in normal font (white) (with courts in bold (grey)). Based on the tests of differences, the constraints can be grouped into 5-7 sets according to their reported severity. The sets are shown by the bold boxes. 
Table A5a

Ranking constraints: Low income formerly planned economies (2002-05) and market economies.

\begin{tabular}{|c|c|c|c|c|c|c|c|c|c|c|c|c|c|c|}
\hline Planned; Low-income & $\begin{array}{c}1 \\
\text { MacroInst }\end{array}$ & $\begin{array}{c}2 \\
\text { GovPolicy }\end{array}$ & $\begin{array}{c}3 \\
\text { TaxAdmin }\end{array}$ & $\begin{array}{c}4 \\
\text { Corruption }\end{array}$ & $\begin{array}{r}5 \\
\text { Courts } \\
\end{array}$ & $\begin{array}{c}6 \\
\text { Customs } \\
\end{array}$ & $\begin{array}{c}7 \\
\text { BusLicens } \\
\end{array}$ & $\begin{array}{c}8 \\
\text { CrimeThe }\end{array}$ & $\begin{array}{c}9 \\
\text { InadEducL }\end{array}$ & $\begin{array}{c}10 \\
\text { Electricity }\end{array}$ & $\begin{array}{c}11 \\
\text { LaborReg }\end{array}$ & $\begin{array}{c}12 \\
\text { AccessLand }\end{array}$ & $\begin{array}{c}13 \\
\text { Transport }\end{array}$ & $\begin{array}{c}14 \\
\text { Telecoms } \\
\end{array}$ \\
\hline 1 Macro Instability & 1.76 & & & & & & & & & & & & & \\
\hline 2 Gov Policy Uncertainty & & 1.76 & & & & & & & & & & & & \\
\hline 3 Tax Administration & & & 1.64 & & & & & & & & & & & \\
\hline 4 Corruption & *** & ** & *** & 1.39 & & & & & & & & & & \\
\hline 5 Courts & ** & ** & ** & *** & 1.14 & & & & & & & & & \\
\hline 6 Customs & ** & ** & ** & ** & & 1.08 & & & & & & & & \\
\hline 7 Bus Licensing & ** & ** & ** & ** & & & 1.08 & & & & & & & \\
\hline 8 Crime Theft Disorder & ** & ** & ** & ** & *** & & & 0.95 & & & & & & \\
\hline 9 Inad Educ Labor & ** & ** & ** & ** & *** & ** & ** & & $\underline{0.89}$ & & & & & \\
\hline 10 Electricity & ** & ** & *** & ** & ** & ** & ** & *** & & 0.77 & & & & \\
\hline 11 Labor Regulation & ** & ** & ** & ** & ** & ** & *** & ** & *** & & 0.74 & & & \\
\hline 12 Access Land & ** & ** & ** & ** & ** & ** & ** & ** & ** & & & 0.70 & & \\
\hline 13 Transport & ** & ** & ** & ** & ** & ** & ** & ** & ** & ** & ** & & 0.57 & \\
\hline 14 Telecoms & ** & ** & ** & ** & ** & ** & ** & ** & ** & ** & ** & ** & & 0.49 \\
\hline Market; Low-income & $\begin{array}{c}1 \\
\text { MacroInst }\end{array}$ & $\begin{array}{c}2 \\
\text { GovPolicy }\end{array}$ & $\begin{array}{c}3 \\
\text { Electricity }\end{array}$ & $\begin{array}{c}4 \\
\text { Corruption }\end{array}$ & $\begin{array}{c}5 \\
\text { TaxAdmin }\end{array}$ & $\begin{array}{c}6 \\
\text { CrimeThef }\end{array}$ & $\begin{array}{c}7 \\
\text { InadEducL }\end{array}$ & $\begin{array}{c}8 \\
\text { Transport }\end{array}$ & $\begin{array}{c}9 \\
\text { LaborReg }\end{array}$ & $\begin{array}{c}10 \\
\text { AccessLand }\end{array}$ & $\begin{array}{c}11 \\
\text { BusLicensin }\end{array}$ & $\begin{array}{r}12 \\
\text { gCourts }\end{array}$ & $\begin{array}{c}13 \\
\text { Customs }\end{array}$ & $\begin{array}{c}14 \\
\text { Telecoms }\end{array}$ \\
\hline 1 MacroInstability & 1.86 & & & & & & & & & & & & & \\
\hline 2 GovPolicyUnc & *** & 1.57 & & & & & & & & & & & & \\
\hline 3 Electricity & ** & & 1.57 & & & & & & & & & & & \\
\hline 4 Corruption & ** & & & 1.52 & & & & & & & & & & \\
\hline 5 TaxAdministration & ** & ** & *** & *** & 1.34 & & & & & & & & & \\
\hline 6 CrimeTheftDisorder & ** & ** & ** & ** & *** & 1.14 & & & & & & & & \\
\hline 7 InadEducLabor & *** & ** & *** & *** & ** & & 1.10 & & & & & & & \\
\hline 8 Transport & ** & ** & ** & ** & ** & *** & *** & 0.92 & & & & & & \\
\hline 9 LaborReg & ** & ** & ** & ** & ** & ** & ** & & 0.90 & & & & & \\
\hline 10 AccessLand & ** & ** & ** & ** & ** & ** & ** & & & 0.88 & & & & \\
\hline 11 BusLicensing & ** & ** & ** & ** & ** & ** & ** & & & & 0.88 & & & \\
\hline 12 Courts & ** & ** & ** & ** & ** & ** & ** & *** & & & & 0.80 & & \\
\hline 13 Customs & ** & ** & ** & ** & ** & ** & ** & ** & *** & *** & ** & & 0.74 & \\
\hline 14 Telecoms & ** & ** & ** & ** & ** & ** & ** & ** & ** & ** & ** & ** & & 0.67 \\
\hline
\end{tabular}


Table A5b

Ranking constraints: High income formerly planned economies (2002-5) and market economies.

\begin{tabular}{|c|c|c|c|c|c|c|c|c|c|c|c|c|c|c|}
\hline Planned; High-income & $\begin{array}{c}1 \\
\text { GovPolicy }\end{array}$ & $\begin{array}{c}2 \\
\text { MacroInst }\end{array}$ & $\begin{array}{c}3 \\
\text { TaxAdmin }\end{array}$ & $\begin{array}{r}4 \\
\text { Courts }\end{array}$ & $\begin{array}{c}5 \\
\text { Corruption }\end{array}$ & $\begin{array}{c}6 \\
\text { LaborReg }\end{array}$ & $\begin{array}{c}7 \\
\text { InadEducL }\end{array}$ & $\begin{array}{c}8 \\
\text { CrimeTheft }\end{array}$ & $\begin{array}{c}9 \\
\text { BusLicens }\end{array}$ & $\begin{array}{c}10 \\
\text { Customs }\end{array}$ & $\begin{array}{c}11 \\
\text { AccessLand }\end{array}$ & $\begin{array}{c}12 \\
\text { Transport }\end{array}$ & $\begin{array}{c}13 \\
\text { Electricity }\end{array}$ & $\begin{array}{c}14 \\
\text { Telecoms }\end{array}$ \\
\hline 1 Gov Policy Uncertainty & 1.80 & & & & & & & & & & & & & \\
\hline 2 Macro Instability & & 1.70 & & & & & & & & & & & & \\
\hline 3 TaxAdministration & *** & *** & 1.51 & & & & & & & & & & & \\
\hline 4 Courts & ** & ** & ** & 1.24 & & & & & & & & & & \\
\hline 5 Corruption & ** & ** & ** & & 1.17 & & & & & & & & & \\
\hline 6 LaborReg & ** & ** & ** & & & 1.16 & & & & & & & & \\
\hline 7 InadEducLabor & ** & ** & ** & & & & 1.15 & & & & & & & \\
\hline 8 CrimeTheftDisorder & ** & ** & ** & *** & ** & *** & ** & 0.96 & & & & & & \\
\hline 9 BusLicensing & ** & ** & ** & ** & ** & ** & ** & & 0.93 & & & & & \\
\hline 10 Customs & ** & ** & ** & ** & ** & ** & ** & * & & 0.80 & & & & \\
\hline 11 AccessLand & ** & ** & ** & ** & ** & ** & ** & ** & ** & ** & 0.63 & & & \\
\hline 12 Transport & ** & *** & ** & ** & ** & ** & ** & ** & ** & ** & & 0.58 & & \\
\hline 13 Electricity & ** & ** & ** & ** & ** & ** & ** & ** & ** & ** & & & 0.55 & \\
\hline 14 Telecoms & ** & ** & ** & ** & ** & ** & ** & ** & ** & ** & ** & * & & 0.44 \\
\hline Market; High-income & $\begin{array}{c}1 \\
\text { MacroInst }\end{array}$ & $\begin{array}{c}2 \\
\text { GovPolicy }\end{array}$ & $\begin{array}{c}3 \\
\text { Corruption }\end{array}$ & $\begin{array}{c}4 \\
\text { InadEducL }\end{array}$ & $\begin{array}{c}5 \\
\text { LaborReg }\end{array}$ & $\begin{array}{c}6 \\
\text { TaxAdmin }\end{array}$ & $\begin{array}{c}7 \\
\text { CrimeTheft }\end{array}$ & $\begin{array}{c}8 \\
\text { BusLicens }\end{array}$ & $\begin{array}{r}9 \\
\text { Courts }\end{array}$ & $\begin{array}{c}10 \\
\text { Electricity }\end{array}$ & $\begin{array}{c}11 \\
\text { Transport }\end{array}$ & $\begin{array}{c}12 \\
\text { Customs }\end{array}$ & $\begin{array}{c}13 \\
\text { Telecoms }\end{array}$ & $\begin{array}{c}14 \\
\text { AccessLand }\end{array}$ \\
\hline 1 MacroInstability & 2.05 & & & & & & & & & & & & & \\
\hline 2 GovPolicyUnc & *** & 1.45 & & & & & & & & & & & & \\
\hline 3 Corruption & ** & ** & 1.21 & & & & & & & & & & & \\
\hline 4 InadEducLabor & ** & ** & & 1.12 & & & & & & & & & & \\
\hline 5 LaborReg & ** & ** & *** & & 1.07 & & & & & & & & & \\
\hline 6 TaxAdministration & ** & ** & ** & & & 1.04 & & & & & & & & \\
\hline 7 CrimeTheftDisorder & ** & ** & ** & ** & & & 0.97 & & & & & & & \\
\hline 8 BusLicensing & ** & ** & ** & ** & ** & ** & ** & 0.80 & & & & & & \\
\hline 9 Courts & ** & ** & ** & ** & ** & ** & ** & & 0.77 & & & & & \\
\hline 10 Electricity & ** & ** & ** & ** & ** & ** & ** & & & 0.71 & & & & \\
\hline 11 Transport & ** & ** & ** & ** & ** & ** & ** & ** & ** & *** & 0.54 & & & \\
\hline 12 Customs & ** & ** & ** & ** & ** & ** & ** & ** & ** & ** & & 0.45 & & \\
\hline 13 Telecoms & ** & ** & ** & ** & ** & ** & ** & ** & ** & ** & & & 0.42 & \\
\hline 14 AccessLand & ** & *** & ** & ** & ** & ** & ** & ** & ** & ** & * & & & 0.41 \\
\hline
\end{tabular}


Table A6a

Ranking constraints: Low income formerly planned economies (2008) and market economies.

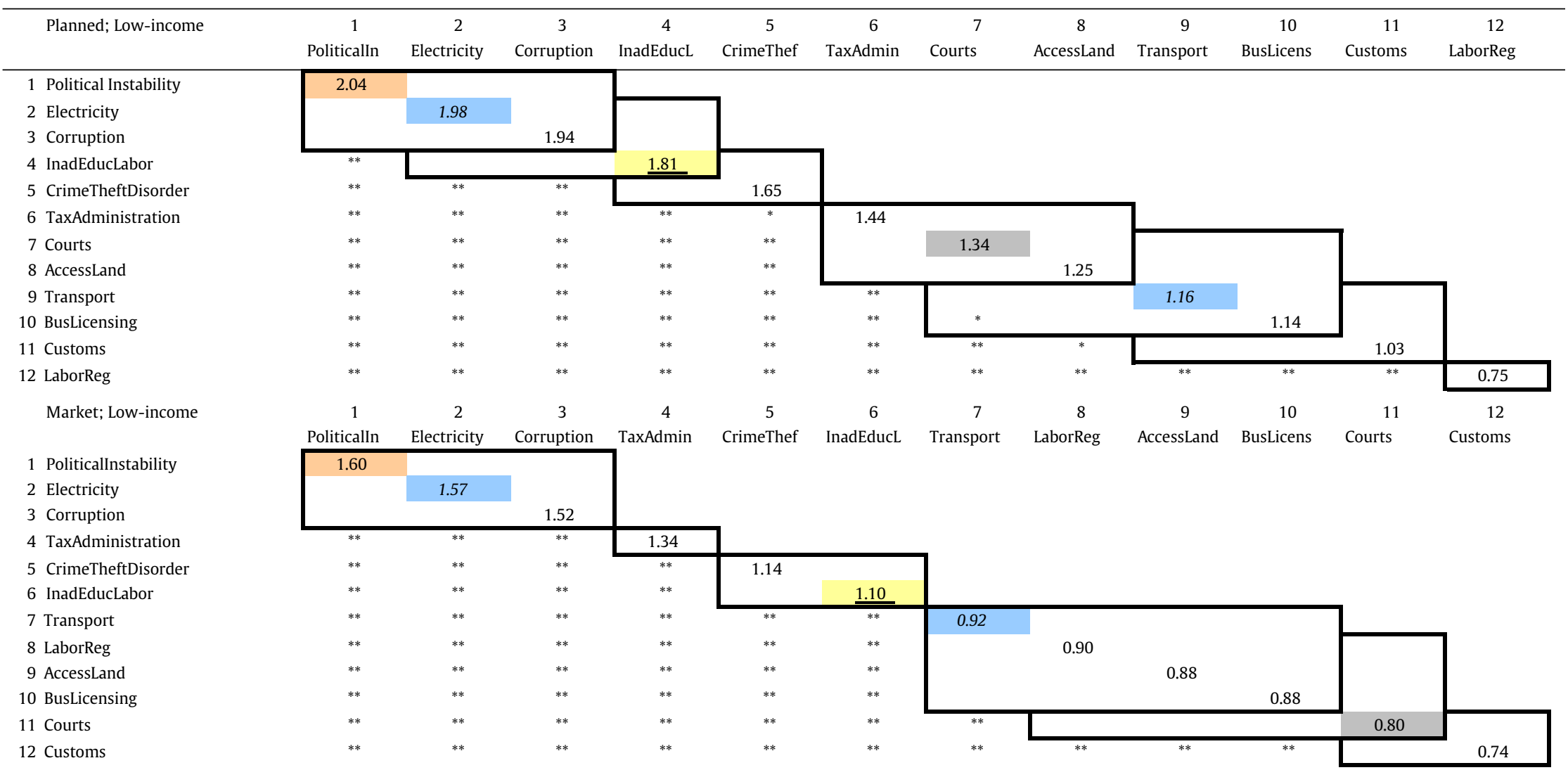


Table A6b

Ranking constraints: High income formerly planned economies (2008) and market economies.

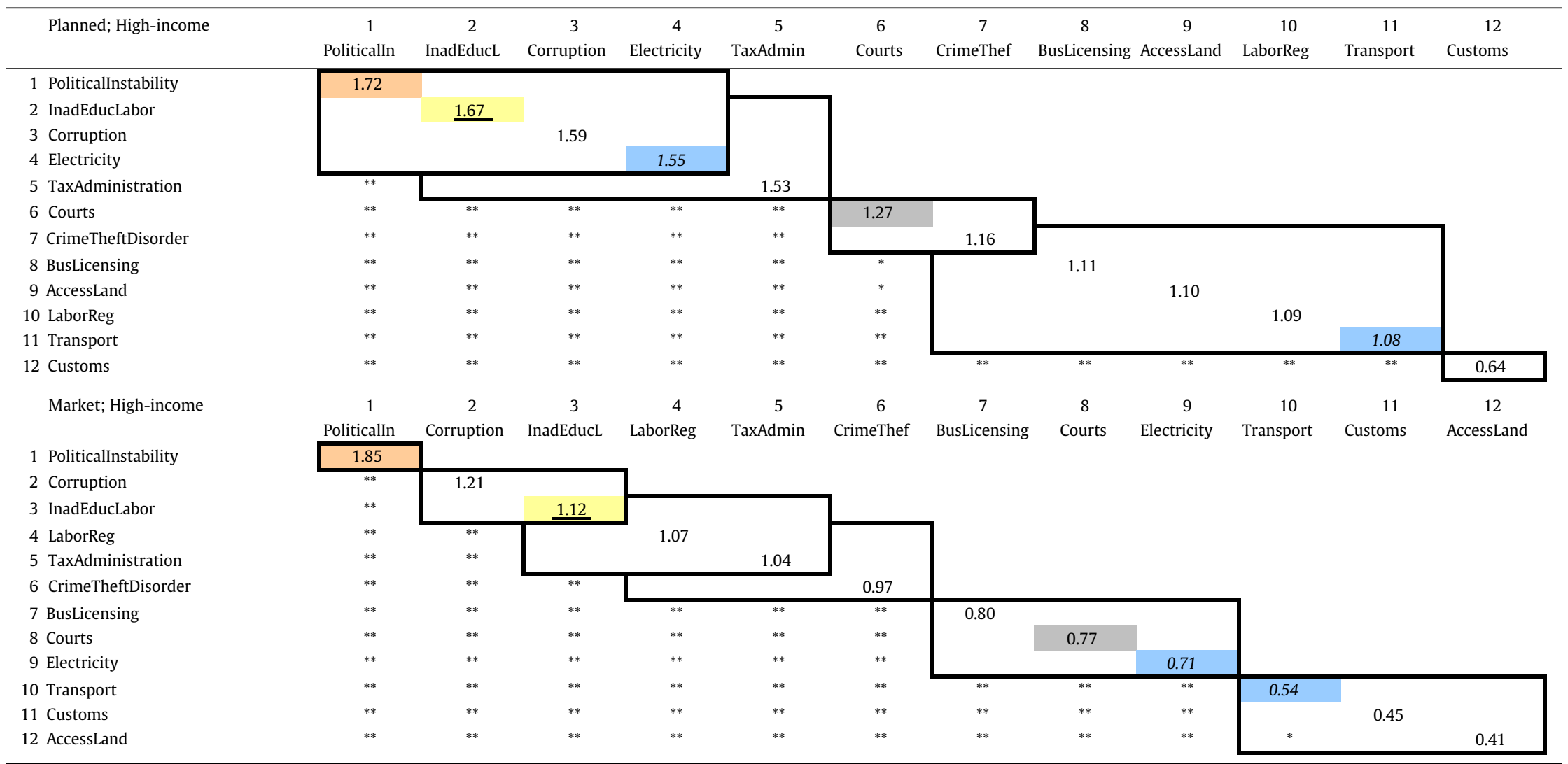




\section{References}

Aghion, P., Schankerman, M., 1999. Competition, entry and the social returns to infrastructure in transition economies. The Economics of Transition 7, 79-101. Allen, R.C., 2003. Farm to Factory: A Reinterpretation of the Soviet Industrial Revolution. Princeton U.P., Princeton.

Allen, R.C., 2012. Technology and the great divergence: Global economic development since 1820. Explorations in Economic History 49, 1-16.

Beck, T., Demirguc-Kunt, A., Maksimovic, V., 2005. Financial and legal constraints to firm growth: does size matter? Journal of Finance 60, $137-178$.

Broadberry, S., Klein, A., 2008. Aggregate and per capita GDP in Europe, 1870-2000: continental, regional and national data with changing boundaries. Conference Paper (http://www.cepr.org/meets/wkcn/1/1699/papers/Broadberry_Klein.pdf Source: file EuropeGDP2dataset.xls, downloaded 27.12.2011).

Broadberry, S., Klein, A., 2011. When and why did Eastern European economies begin to fail? Lessons from a Czechoslovak/UK productivity comparison, 1921-1991. Explorations in Economic History 48, 37-52.

Capek, A., Sazama, G., 1993. Czech and Slovak economic relations. Europe-Asia Studies 45 (2), 211-235.

Carbajo, J., Fries, S., 1997. Restructuring Infrastructure In Transition Economies. EBRD Working Paper, 24.

Carlin, W., Schaffer, M., 2009. Public Infrastructure Constraints on Growth in the Transition Economies: The Legacy of Communism and Evidence from Enterprise Surveys 1999-2008. Background Paper. World Bank, Washington DC.

Carlin, W., Schaffer, M., 2012. Understanding the Business Environment in South Asia: Evidence from Firm-Level Surveys. World Bank Policy Research Working Paper, 6160, World Bank, Washington DC.

Carlin, W., Schaffer, M., Seabright, P., 2006. What are the real bottlenecks? A Lagrangian approach to identifying constraints on growth from survey data. CEPR Discussion Paper, 5719.

Carlin, W., Schaffer, M., Seabright, P., 2010. A framework for cross-country comparisons of public infrastructure constraints on firm growth. CEPR Discussion Paper, 7662

Commander, S., Svejnar, J., 2011. Business environment, exports, ownership, and firm performance. The Review of Economics and Statistics 93 (1), 309-337.

Commander, S., Nikoloski, Z., 2011. Institutions and economic performance: what can be explained? Review of Economics and Institutions 2 (2), http://dx.doi.org/ 10.5202/rei.v2i2.33.

Crafts, N., Toniolo, G., 2010. Aggregate growth. In: Broadberry, S., O'Rourke, K. (Eds.), The Cambridge Economic History of Modern Europe. Cambridge University Press, Cambridge, pp. 1950-2005.

Dethier, J.J., Hirn, M., Straub, S., 2010. Explaining enterprise performance in developing countries with business climate survey data. World Bank Research Observer 26 (2), 258-309.

Dollar, D., Hallward-Driemeier, M., Mengistae, T., 2005. Investment climate and firm performance in developing economies. Economic Development and Cultural Change 54 (1), 1-31.

Durlauf, S.N., Johnson, P., Temple, J., 2005. Growth econometrics. In: Aghion, P., Durlauf, S.N. (Eds.), Handbook of Economic Growth. North-Holland, Amsterdam. EBRD, 1996. Transition Report: Infrastructure and Savings. EBRD, London.

Feinberg, R., Meurs, M., 2008. Market reform and infrastructure development in transition economies. Review of Development Economics 12 (2), $237-247$.

Gomulka, S., 1986. Soviet growth slowdown: duality, maturity and innovation. American Economic Review 76 (2)Papers and Proceedings, pp. 170-174 (May).

Gomulka, S., 1988. The Gerschenkron phenomenon and systemic factors in the post-1975 growth slowdown. European Economic Review 32, 451-458.

Good, D.F., Ma, T., 1999. The economic growth of Central and Eastern Europe in comparative perspective, 1970-1989. European Review of Economic History 2, $103-137$.

Gregory, M.B., 1973. Regional economic development in Yugoslavia. Soviet Studies 25 (2), 213-222.

Hallward-Driemeier, M., Aterido, R., 2009. Comparing apples with...apples: how to make (more) sense of subjective rankings of constraints to business. World Bank Policy Research Working Paper, 5054.

Hallward-Driemeier, M., Wallstein, S.J., Xu, L.C., 2006. Ownership, investment climate and firm performance. The Economics of Transition 14 (4), 629-647.

Hedegaard, L., Lindström, B., 1998. The NEBI Yearbook: North European and Baltic Sea Integration. Springer, Heidelberg.

Henze, P.B., 1949. The economic development of Soviet Central Asia to the eve of world war II. Journal of The Royal Central Asian Society 36 (3-4), 278-296.

Kaufmann, D., Kraay, A., Mastruzzi, M., 2010. The Worldwide Governance Indicators: Methodology and Analytical Issues. World Bank Policy Research Working Paper, 5430

Lenin, V.I. (1920). Collected Works, Volume 31, April - December 1920, ed. and trans. Jullius Katzer (Moscow: Progress Publishers, 1966), pp. 496-518. (Address to the 8th All-Russia Congress of Soviets).

Maddison, A., 2009. Statistics on world population, GDP and per capita GDP, 1-2008 AD. University of Groningen. (http://www.ggdc.net/MADDISON/oriindex. htm).

Mitra, P., Selowsky, M., Zalduendo, J., 2010. Turmoil at twenty: recession, recovery, and reform in Central and Eastern Europe and the former Soviet Union. World Bank, Washington.

Roland, G., 2000. Transition and Economics: Politics, Markets and Firms. MIT Press, Cambridge, MA.

Svejnar, J., 2002. Transition economies: performance and challenges. The Journal of Economic Perspectives 16 (1), 3-28.

von Hirschhausen, C., 2002. Modernizing Infrastructure in Transformation Economies: Paving the Way to European Enlargement. Edward Elgar, Northampton, MA. 